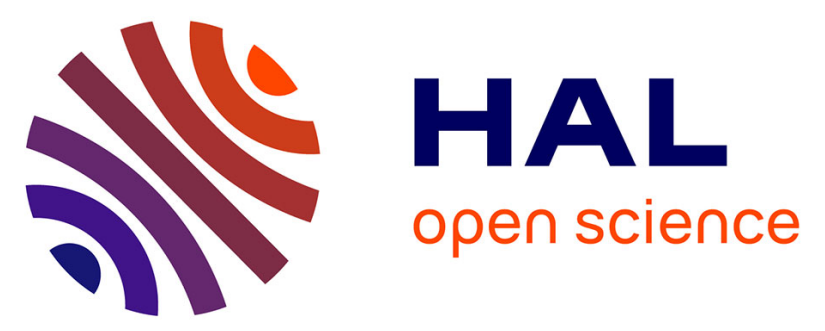

\title{
Evolution of the crustal magma plumbing system during the build-up to the 22-ka caldera-forming eruption of Santorini (Greece)
}

\author{
G.N. Fabbro, Timothy H. Druitt, Stéphane Scaillet
}

\section{To cite this version:}

G.N. Fabbro, Timothy H. Druitt, Stéphane Scaillet. Evolution of the crustal magma plumbing system during the build-up to the 22-ka caldera-forming eruption of Santorini (Greece). Bulletin of Volcanology, 2013, 75, pp.1-22. 10.1007/s00445-013-0767-5 . insu-00914757

HAL Id: insu-00914757

https://hal-insu.archives-ouvertes.fr/insu-00914757

Submitted on 6 Dec 2013

HAL is a multi-disciplinary open access archive for the deposit and dissemination of scientific research documents, whether they are published or not. The documents may come from teaching and research institutions in France or abroad, or from public or private research centers.
L'archive ouverte pluridisciplinaire HAL, est destinée au dépôt et à la diffusion de documents scientifiques de niveau recherche, publiés ou non, émanant des établissements d'enseignement et de recherche français ou étrangers, des laboratoires publics ou privés. 


\section{Evolution of the crustal magma plumbing system during the build-up to the 22 ka caldera-forming eruption of Santorini (Greece)}

GN Fabbro*a,b,c, TH Druitta,b,c, S Scaillet ${ }^{\mathrm{d}}$

a Clermont Université, Université Blaise Pascal, Laboratoire Magmas et Volcans, BP 10448, F63000 Clermont-Ferrand, France.

b CNRS, UMR 6524, LMV, F-63038 Clermont-Ferrand, France.

c IRD, R 163, LMV, F-63038 Clermont-Ferrand, France.

d Institut des Sciences de la Terre d'Orleans (ISTO), INSU-CNRS - Université d'Orleans, 1A rue de la Ferollerie, 45071 Orleans, France.

* Corresponding author:

Email: g.fabbro@opgc.univ-bpclermont.fr

Phone: $\quad+33(0) 647176058$

Fax: $\quad+33(0) 473346744$ 


\section{Abstract}

The formation of caldera-sized reservoirs of crystal-poor silicic magma requires the generation of large volumes of silicic melt, followed by the segregation of that melt and its accumulation in the upper crust. The $21.8 \pm 0.4$ ka Cape Riva eruption of Santorini discharged $>10$ $\mathrm{km}^{3}$ of crystal-poor dacitic magma along with $<<1 \mathrm{~km}^{3}$ of hybrid andesite, and collapsed a preexisting lava shield. We have carried out a field, petrological, chemical and high-resolution ${ }^{40} \mathrm{Ar} /$ ${ }^{39} \mathrm{Ar}$ chronological study of a sequence of lavas discharged prior to the Cape Riva eruption in order to constrain the crustal residence time of the Cape Riva magma reservoir. The lavas were erupted between 39 and $25 \mathrm{ka}$, forming a $\sim 2 \mathrm{~km}^{3}$ complex of dacitic flows, coulees and domes up to $200 \mathrm{~m}$ thick (Therasia dome complex). The Therasia dacites show little chemical variation with time, suggesting derivation from one or more thermally buffered reservoirs. Minor pyroclastic layers occur intercalated within the lava succession, particularly near the top. A prominent pumice fall deposit probably correlates with the $26 \mathrm{ka} \mathrm{Y}-4$ ash layer found in deep-sea sediments SE of Santorini. One of the last Therasia lavas to be discharged was a hybrid andesite formed by the mixing of dacite and basalt. The Cape Riva eruption occurred no more than $2,800 \pm 1,400 \mathrm{y}$ after the final Therasia activity. The Cape Riva dacite is similar in major element composition to the Therasia dacites, but is poorer in $\mathrm{K}$ and most incompatible trace elements (e.g., $\mathrm{Rb}, \mathrm{Zr}$, LREE). The same chemical differences are observed between the Cape Riva and Therasia hybrid andesites, and between the calculated basaltic mixing endmembers of each series. The Therasia and Cape Riva dacites are distinct silicic magma batches and are not related by shallow processes of crystal fractionation or assimilation. The Therasia lavas were therefore not simply precursory leaks from the growing Cape Riva magma reservoir. The change 21.8 ky ago from a magma series richer in incompatible elements to one poorer in those elements is one step in the well documented decrease 
with time of incompatibles in Santorini magmas over the last $530 \mathrm{ky}$. The two dacitic magma batches are interpreted to have been emplaced sequentially into the upper crust beneath the summit of the volcano, the first (Therasia) then being partially, or wholly, flushed out by the arrival of the second (Cape Riva). This constrains the crustal residence time of the Cape Riva reservoir to less than $2,800 \pm 1,400$ years, and the associated time-averaged magma accumulation rate to $>0.004 \mathrm{~km}^{3} / \mathrm{y}$. Rapid ascent and accumulation of the Cape Riva dacite may have been caused by an increased flux of mantle-derived basalt into the crust, explaining the occurrence of hybrid andesites (formed by the mixing of olivine basalt and dacite in approximately equal proportions) in the Cape Riva and late Therasia products. Pressurization of the upper crustal plumbing system by sustained, high-flux injection of dacite and basalt may have triggered the transition from prolonged, largely effusive activity to explosive eruption and caldera collapse.

Keywords: Santorini, magma reservoirs, melt accumulation, residence timescales, calderas

\section{Introduction}

Caldera-forming ignimbrite eruptions discharge large volumes $\left(1-10^{3} \mathrm{~km}^{3}\right)$ of silicic magma from shallow reservoirs (Smith 1979; Mason et al. 2004; Miller and Wark 2008). The processes that generate such reservoirs, and the timescales on which those processes operate, are not completely understood (e.g., Costa 2008; Bachmann and Bergantz 2008; Gelman et al. 2013). This is particularly true of caldera systems such as Santorini that erupt crystal-poor silicic magmas (Bachmann and Bergantz 2004; Hildreth and Wilson 2007; Wilson and Charlier 2009; Druitt et al. 2012; Gualda et al. 2012; Allan et al. 2013)

The formation of caldera-sized reservoirs of crystal-poor silicic magma requires the generation of large volumes of silicic melt, followed by the segregation of that melt and its 
accumulation in the upper crust (Lindsay et al. 2001; Bachmann and Bergantz 2004, 2008). Large volumes of silicic melt are generated in crustal hot zones by fractional crystallization of mantlederived basalt, partial melting of crustal rocks, defrosting of incompletely crystallized plutons (Hildreth 1981; Hildreth and Moorbath 1988; Annen et al. 2006; Solano et al. 2012). Fractional crystallization is driven by outgassing and cooling of magma during ascent (Blundy and Cashman 2008). Partial melting of crustal rocks and pre-existing plutons is driven by heat advected by mantle-derived magma and magmatic volatiles (Hildreth 1981; Bachmann and Bergantz 2006; Huber et al. 2011). Silicic melt generation can occur over timescales of $10^{5}$ to $10^{1}$ years (Brown and Fletcher 1999; Charlier et al. 2005; Bachmann and Bergantz 2006; Burgisser and Bergantz 2011; Klemetti et al. 2011; Huber et al. 2011). Magmatic crystal mushes generated by these processes may remain at depth, or may erupt en masse to form crystal-rich ignimbrites (the monotonous intermediates of Hildreth 1981).

The formation of reservoirs of crystal-poor silicic magma requires the separation of melt from residual mush crystals, and the accumulation of that melt at a particular crustal level—either in situ within the mush (e.g. Bachmann and Bergantz 2004), or at higher levels in the plumbing system (e.g. Allan et al. 2013). The rate at which silicic melt can separate from crystals is limited by its high viscosity (McKenzie 1985; Bachmann and Bergantz 2008). Possible mechanisms include gravitational separation through hindered settling of individual crystals, or compaction of a porous crystal network (Bachmann and Bergantz 2004). Melt migration driven by shear or gas filter pressing may generate small, local segregations (Stevenson 1989; Brown and Solar 1998; Sisson and Bacon 1999) that are subsequently concentrated into large melt lenses. Runaway reservoir growth requires rates of heat (and hence magma) input high enough to limit crystallisation and avoid plutonic death (Annen 2009; Schöpa and Annen 2013; Gelman et al. 2013).

Estimates of melt accumulation timescales for crystal-poor silicic magmas vary widely. Assembly of the rhyolitic magma reservoir that discharged the $600-650 \mathrm{~km}^{3}$ Bishop Tuff has 
been estimated as $\sim 10^{5} \mathrm{y}$, based on zircon ages and on the chemical similarity between the Bishop magma and earlier rhyolites (Hildreth and Wilson 2007). However, element diffusion profiles and melt inclusion faceting in Bishop quartz crystals yield much shorter timescales $\left(10^{3}-10^{2} \mathrm{y}\right.$; Wark et al. 2007; Gualda et al. 2012). The reservoir that fed the $530 \mathrm{~km}^{3}$ Oruanui Ignimbrite at Taupo was assembled over 1600 years (Wilson and Charlier 2009; Allan et al. 2013), and that of the $\sim 35 \mathrm{~km}^{3}$ post-Oruanui ' $\mathrm{Y}$ ' eruption was assembled over $<1000$ years (Sutton et al. 2000). The magma reservoir of the $30-60 \mathrm{~km}^{3}$ Minoan eruption at Santorini underwent a spurt of rapid growth in the centuries preceding venting (Druitt et al. 2012). Ascent of silicic melt into shallow reservoirs can occur in pulses with durations that are short compared to the repose period between eruptions (Druitt et al. 2012; Parks et al. 2012).

In this paper we study a sequence of silicic and intermediate lavas at Santorini that were discharged prior to $\mathrm{a} \gtrsim 10 \mathrm{~km}^{3}$ caldera-forming eruption of crystal-poor silicic magma (the $22 \mathrm{ka}$ Cape Riva eruption). The lavas record the development of the crustal plumbing system over many thousands of years preceding the Cape Riva eruption. We present field, petrological and chemical data for these lavas, along with new, high-precision ${ }^{40} \mathrm{Ar} /{ }^{39} \mathrm{Ar}$ ages. The results enable us to place constraints on the residence timescale of the Cape Riva magma reservoir in the upper crust.

\section{Geological Setting}

Santorini Volcano lies on the Hellenic volcanic arc, which stretches between Greece and Turkey through the Aegean Sea, and owes its origin to the subduction of the African plate beneath the Eurasian plate (Le Pichon and Angelier 1979; Papazachos et al. 2000; Nocquet 2012). Santorini lies on continental crust about $23 \mathrm{~km}$ thick (Tirel et al. 2004; Karagianni et al. 2004). The boundary between the upper crust and lower crust lies at about $15 \mathrm{~km}$ depth (Konstantinou 2010). 
The volcanic history of Santorini has been described by Druitt et al. (1999). Volcanism commenced about $650 \mathrm{ka}$ (Fig. 1). From about 360 ka onwards, activity consisted of multiple large $\left(>1 \mathrm{~km}^{3}\right)$ explosive eruptions alternating with periods of lava extrusion and minor explosive events. The last major eruption (Minoan eruption) occurred about 1639-1616 BCE (Manning et al. 2006) and discharged 30-60 km³ of magma (Pyle et al. 1990; Sigurdsson et al. 2006). Since the Minoan eruption there have been at least ten dacitic effusive eruptions, building up the Kameni intra-caldera volcano (Pyle and Elliott 2006).

Santorini magmas are calc-alkaline to mildly tholeiitic, and range from basalt to rhyodacite in composition (Druitt et al. 1999). The silicic magmas are generally poor in phenocrysts $(<5-20$ vol\% on a vesicle-free basis). Phase-equilibria experiments (Andújar et al. 2010) have shown that mantle-derived basalt ascending beneath Santorini stagnates and fractionates to basaltic andesite at about $4 \mathrm{~kb}\left(\sim 15 \mathrm{~km}\right.$, assuming a mean upper crustal density of $2640 \mathrm{~kg} \cdot \mathrm{m}^{-3}$; Konstantinou 2010), near the boundary between the upper and lower crust. The silicic magmas discharged during large eruptions are stored in the upper crust at $2 \pm 0.5 \mathrm{~kb}(\sim 8 \mathrm{~km})$ immediately prior to eruption (Cadoux et al. 2013).

Our study focuses on the products of the volcano from the period between 70 and $22 \mathrm{ka}$ (Fig. 2). About $70 \mathrm{ky}$ ago a caldera formed in the northern half of the volcanic field, probably as a result of one or more explosive eruptions (Druitt et al. 1999). Eruption of basaltic to andesitic lavas then built up a lava shield within this caldera (Skaros lava shield; 70-54 ka). The shield grew to over $350 \mathrm{~m}$ above present-day sea level, filling and partly overspilling the caldera (Huijsmans 1985; Huijsmans and Barton 1989; Druitt et al. 1999). The volume of the shield has been estimated at about $12 \mathrm{~km}^{3}$ from reconstructions based on lavas exposed in the caldera cliffs (Druitt et al. 1999). Construction of the shield culminated 54 ky ago with an explosive eruption called Upper Scoria 2, which generated a rhyodacitc Plinian fall deposit overlain by voluminous andesitic scoria flows (Mellors and Sparks 1991). Following Upper Scoria 2, about $2 \mathrm{~km}^{3}$ of silicic lavas were extruded 
across the summit and western flank of Skaros to form the Therasia dome complex.

At $\sim 22 \mathrm{ka}$, a large silicic explosive eruption (the Cape Riva eruption) collapsed the Skaros-Therasia edifice (Druitt and Francaviglia 1992). The eruption had an initial Plinian phase from a vent located somewhere in the northern part of the volcanic field. This was followed by the discharge of pyroclastic flows that laid down welded ignimbrite, non-welded ignimbrite and lithicrich lag deposits up to $25 \mathrm{~m}$ thick all over the islands (Druitt and Sparks 1982). The volume of magma discharged during the Cape Riva eruption is poorly constrained, since most of the ignimbrite lies under the sea. However distal tephra from the eruption, recognised as the Y-2 marine ash bed, is found over a very wide area of the eastern Mediterranean and as far north as the Island of Lesvos and the Sea of Marmara (Keller et al. 1978; Thunell et al. 1979; Federman and Carey 1980; Wulf et al. 2002; Margari et al. 2007; Asku et al. 2008). The dispersal area and thickness of the Y-2 ash are similar to those of the Z-2 ash from the Minoan eruption, suggesting that the Cape Riva and Minoan eruptions were of comparable magnitude (Narcisi and Vezzoli 1999; Asku et al. 2008). Graphical integration of Y-2 ash thicknesses recorded by the above authors yields a minimum volume of $\sim 10 \mathrm{~km}^{3}$. Since distal ashes commonly have comparable volumes to the parent ignimbrite (e.g. Pyle 1990), we very approximately infer a volume of $>20 \mathrm{~km}^{3}$ for the Cape Riva products, equivalent to $>10 \mathrm{~km}^{3}$ of magma.

Remnants of the Skaros and Therasia lavas are widely exposed in the northern half of the present day complex. The Skaros lavas are thickest (up to $300 \mathrm{~m}$ ) on Thera, and the Therasia lavas are thickest (up to $200 \mathrm{~m}$ ) on Therasia. The products of the Therasia and Cape Riva eruptions are the focus of the present paper.

\section{Methodology}


Lavas of the Therasia dome complex cropping out in the caldera cliffs were photographed from a boat, and the photos were merged using computer software and interpreted to produce synthetic sections detailing the relationships and lateral extents of individual lavas. Correlations were checked by onland observations, and stratigraphic relationships were mapped out. Pumice layers and palaeosols between the lavas were also mapped.

Lavas from four key stratigraphic levels were dated using the ${ }^{40} \mathrm{Ar} /{ }^{39} \mathrm{Ar}$ technique. The groundmass of each sample was separated, hand-picked, and cleaned in an ultrasonic bath of dilute nitric acid prior to irradiation in the Cd-lined fast neutron slot $\beta 1$ of the Osiris reactor (CEA, Saclay) with sanidine ACR (1.206 $\pm 0.002 \mathrm{Ma}$, Renne et al. 2010, 2011). Upon receipt from the nuclear reactor, the samples were analysed by multiple laser fusion using a high-sensitivity MM5400 mass spectrometer operated in pulse-counting mode following the experimental and correction procedures of Scaillet et al. $(2008,2011)$. More than 25 individual ages were extracted from each sample via a two-step fusion of $\sim 10 \mathrm{mg}$ of groundmass replicates (see procedural details in Scaillet et al. 2011).

Representative samples of lava and pumice from the Therasia complex, and pumice and scoria from the Cape Riva deposits, were collected for chemical analysis. All samples were chosen to be as fresh and glassy as possible. Groundmass separates of selected lavas were obtained in order to analyse the compositions of the melt phases of the magmas. This was done using a magnetic separator, and interstitial glasses of pumice samples were concentrated by flotation in water. Remaining crystals were then removed by hand picking under an optical microscope. Major elements were analysed using inductively coupled plasma atomic emission spectroscopy (ICP AES) at the Laboratoire Magmas et Volcans, Université Blaise Pascal, Clermont-Ferrand. Measurements were calibrated using three standards: a blank $\left(\mathrm{LiBO}_{2}\right)$, basalt $(\mathrm{BR})$ and granite $(\mathrm{GH})$. The DR$\mathrm{N}$ and BHVO-2 standards were then passed as unknowns. Trace elements were analysed using inductively coupled plasma mass spectroscopy (ICP MS) at the Institut des Sciences de la Terre, 
Université de Grenoble. The ICP MS analyses were calibrated using the BR standard, and the BVHO-2 and AGV-1 standards were passed as unknowns. Some previous Cape Riva samples of Druitt et al. (1999) were re-analysed for comparison with the data of those authors. These comparisons showed good agreement between the two datasets for the elements used in the present paper.

Phenocryst contents were calculated by mass balance from $\mathrm{Zr}$ concentrations in whole rock and groundmass analyses of individual samples, by assuming that the crystals contain no Zr. Zirconium behaves incompatibly in all magmas younger than $530 \mathrm{ka}$ at Santorini (Huijsmans 1985; Druitt et al. 1999), and zircon has never been observed as a mineral phase in those magmas. Proportions of the different phenocryst phases were estimated by image analysis of thin sections using the ImageJ software package (Rasband 1997). Mineral compositions were analysed using the Cameca SX 100 electron microprobe at the Laboratoire Magmas et Volcans, Université Blaise Pascal, Clermont-Ferrand, using a beam current of $15 \mathrm{nA}$. Glasses were analysed with a beam current of $4 \mathrm{nA}$ and a defocussed beam (10-15 $\mu \mathrm{m})$ in order to limit $\mathrm{Na}$ loss. Fe-Ti oxide compositions were analysed either in touching pairs or in pairs (that would have been in contact with the same melt) adhering to the outside of the same pyroxene crystal. Magmatic temperatures and oxygen fugacities were calculated with the ILMAT software package (Lepage 2003) using the formulation of Andersen and Lindsley (1985) and Stormer (1983). This formulation has been found to give good agreement with data from phase-equilibria experiments within the $850-950{ }^{\circ} \mathrm{C}$ temperature range (Cottrell et al. 1999; Blundy and Cashman 2008). Values we obtained using the formulation of Ghioso and Evans (2008) are 10-20 ${ }^{\circ} \mathrm{C}$ and $0.2-0.4 \mathrm{fO}_{2} \log$ units higher than those obtained using Andersen and Lindsley (1988), for the temperature range in question.

\section{Results}




\section{Field and stratigraphic relationships}

Photographs and sketches of the Therasia cliffs are shown in Fig. 3; schematic diagrams summarising the architecture of the lavas are shown in Fig. 4 (with individual lavas numbered for

reference). Lavas of the Therasia dome complex overlie Upper Scoria 2, separated by a palaeosol. They make up much of the present-day cliffs of Therasia (flows 1-24), and one lava crops out at the top of the caldera wall north of Fira town (flow 25). Thin lava flows occupying the same stratigraphic position (between Upper Scoria and Cape Riva) occur beneath the town of Oia (flow 26; Andesite of Oia of Druitt et al. 1999).

The lava succession on Therasia consists of many individual lava flows, coulees and domes (termed flows for short). Individual flows range in thickness up to $60 \mathrm{~m}$ (Fig. 5a); thin flows tend to be dark grey and glassy, whereas thicker ones are pale grey and de-vitrified. Many exhibit flow banding that is most evident in the thicker, de-vitrified flows. The greatest accumulated thicknesses occur near Cape Tripiti ( 150 m) and Mount Viglos ( 200 m), where, at each location, nine flows are stacked. Correlations of individual flows between the Tripiti and Viglos sections is difficult, as only two flows ( 3 and 4 ) are continuous between them. Flows 1 and 24 are compositionally very similar, and are probably the same flow. This is also true of flows 11 and 22.

Most of the lava flows on Therasia are dacitic to rhyodacitic, with two exceptions. First, the basal flows 1 and 24 are andesitic, and we refer to them jointly as the lower Therasia andesite. Second, the topmost flow on Mount Viglos (flow 22) is also andesitic, and we refer to this (and the compositionally similar flow 11) as the upper Therasia andesite. Enclaves of quenched basaltic magma with crenulated margins occur in some of the lowest lavas (flows 1 and 3) and towards the top of the succession (flows 22 and 25); rare gabbroic enclaves also occur. The widespread distribution of the Therasia lavas show that they were fed from vents extending from the summit to the western flank of the Skaros shield (Fig. 2). The feeder dyke of flow 3 is preserved at Cape 
Tripiti (Fig. 3 b,c). The dyke is oriented NE-SW, parallel to the main dyke trend in northern Thera and the alignment of the recent vents on the Kameni Islands (Heiken and McCoy 1984; Druitt et al. 1999).

At least four dacitic pumice fall units and a phreatomagmatic tuff occur intercalated within the Therasia succession (Fig. 5c). The pyroclastic units are concentrated towards the top of the succession (younger than flow 7 at Tripti, and younger than flow 20 at Viglos), showing an increasing tendency for explosive activity with time during eruption of the Therasia dome complex. A single pumice fall deposit crops out between flows 24 and 27 below Manolas. The most prominent fall deposit is up to a metre thick and widespread in the cliffs of southern Therasia (Fig. 5c). It occurs stratigraphically between lava flows 7 and 8, and is the product of a Plinian not recognized in previous studies. We name this unit the Cape Tripiti pumice fall deposit.

Palaeosols occur at several levels in the Therasia succession. A thick one separates the entire Therasia succession from Upper Scoria 2 (Fig. 5d). Another separates the lower Therasia andesite from overlying dacitic flows, showing that eruption of the lower Therasia andesite was both preceded, and followed, by significant time breaks. Local palaeosols also occur between some of the pyroclastic layers.

The andesite of Oia is both underlain and overlain by thick palaeosols. Long periods therefore separated its eruption from both the preceding Upper Scoria 2 eruption and the subsequent Cape Riva eruption. Four thin pumice fall layers $(5-25 \mathrm{~cm}$ thick) occur within the palaeosol overlying the lava (sequence M11 of Vespa et al. 2006); they may correlate with the pumice layers intercalated within the lavas on Therasia, but this has not been checked chemically.

Products of the Cape Riva eruption are observed to overlie all lavas of the Therasia dome complex. They have been described in detail by Druitt and Sparks (1982), Druitt (1985), and Druitt et al. (1999). The products of the eruption are predominantly dacitic, but minor amounts of andesitic scoria were erupted during the initial Plinian phase. 


\section{Age constraints}

\section{Radiometric dating of the Therasia lavas}

The ages of flows 1, 3, 21 and 25 are reported as probability density plots in Fig. 6, along with the corresponding Gauss plots that reflect the statistical distribution of individual ages for each sample. Complete ${ }^{40} \mathrm{Ar} /{ }^{39} \mathrm{Ar}$ analytical data are reported in Supplementary Table S1 and are summarized in Table 1, along with $2 \sigma$ errors. All four samples exhibit relatively well behaved ${ }^{40} \mathrm{Ar} /$ ${ }^{39} \mathrm{Ar}$ systematics in the form of unimodal density plots, with no (or only slightly) pronounced tails on either side of the mode. The homogeneity of the samples is reflected by the linear arrays formed by individual ages on the Gauss plots, indicating that they follow the distribution expected from the propagated Gaussian experimental errors. One exception is flow 3, which exhibits an age spread in excess of the variance expected from the analytical errors (i.e., excess-error scatter). This sample is, along with flow 1, the least glassy of the four, and both are characterized by slightly higher errors and some excess-error scatter. This suggests that flows 1 and 3 may have been affected by postcooling alteration close to sea level near the base of the sequence, resulting in higher apparent ages (presumably due to $\mathrm{K}$ loss). In contrast, flows 21 and 25 are very glassy and pristine, with unusually tight error bars; especially flow 21.

To account for secondary alteration effects, the data from flows 1 and 3 were statistically screened by computing a weighted mean age using a MSWD cut-off value. This includes only the youngest sub-population conforming to a Gaussian distribution within each sample (see procedure in Gansecki et al. 1996; Scaillet et al. 2011). In every instance, the weighted mean age agrees with the age derived from the best-fit line through the corresponding Gauss-plot array (Fig. 6). In what follows we cite the weighted mean ages.

The ages all are consistent with observed field stratigraphic constraints, as summarized in Fig. 7. The age of the basal flow (flow $1 ; 48.2 \pm 2.4 \mathrm{ka}$ ) is consistent with the presence of a 
palaeosol separating it from the underlying Upper Scoria 2 (previously dated by ${ }^{40} \mathrm{Ar} /{ }^{39} \mathrm{Ar}$ at $54 \pm 3$ ka by Druitt et al. 1999), and with another palaeosol separating it from the overlying flow 3 (39.4 \pm $2.2 \mathrm{ka}$ ). Flow 21 yields an age of $33.2 \pm 1.1 \mathrm{ka}$, and flow 25 (at Fira) gives an age of $24.6 \pm 1.3 \mathrm{ka}$. Taken as a whole, our ${ }^{40} \mathrm{Ar} /{ }^{39} \mathrm{Ar}$ data between the base (48.2 ka) and the top (24.6 ka) of the lava sequence define a $\sim 24$ ky duration for the constuction of the Therasia dome complex

\section{Correlation of the Cape Tripiti Pumice with the Y-4 deep-sea ash layer}

The Cape Tripiti pumice is the most prominent pyroclastic layer in the Therasia sequence, and we have explored the possibility that, like most Plinian eruptions of Santorini, (Keller et al. 1978; Federman and Carey 1980; Vinci 1985; Schwarz 2000; Wulf et al. 2002; Asku et al. 2008), the Cape Tripiti eruption left a recognisable ash layer in deep-sea sediments of the Aegean area. Previous studies have recognized a 2-7 cm-thick ash layer (Y-4 ash) preserved to the SE of Santorini; this ash lies stratigraphically beneath the Cape Riva Y-2 ash layer, and has an age of $25.8 \mathrm{ka}$ estimated by interpolation in the sedimentary sequence of one core (Schwarz 2000). The uncertainty on this age could be $\pm 2 \mathrm{ka}$ (J Keller, pers. comm). The mineralogy of the Y-4 ash (plag, opx, cpx) pinpoints its source to Santorini (Vinci 1985). Schwarz (2000) explored the possibility that the Y-4 correlates with the rhyodacitic Plinian phase of Upper Scoria 2; however, the ${ }^{40} \mathrm{Ar} /$ ${ }^{39} \mathrm{Ar}$ age data described above rule out this correlation, and show that the Y-4 lies chronologically in the period of the Therasia dome complex. We have analysed the interstitial glass of three pumice lumps from the Cape Tripiti deposit, and find excellent agreement with glass composition of the Y4 (Fig. 8, Supplementary Table S2). A 26 ka age for the Cape Tripiti is consistent with all other age constraints (Fig. 7).

\section{Synthesis of published dates for the Cape Riva eruption}

The Cape Riva eruption has been dated previously by radiocarbon on charcoal from beneath the ignimbrite and via $\delta^{18} \mathrm{O}$ wiggle matching in deep-sea sequences hosting the distal equivalent 
Y-2 tephra layer (data and sources in Table 2). Calibration of the raw radiocarbon data against the curve of Fairbanks et al. (2005) returns a mean age of $21.8 \pm 0.4$ ka for Cape Riva (Table 2). This yields an interval of $2,800 \pm 1,400(2 \sigma)$ y between the youngest dated Therasia lava (flow 25) and the Cape Riva eruption. This is a maximum estimate for the interval separating the Cape Riva eruption from the Therasia lavas, since some of the undated flows on Therasia may be younger than flow 25, or a younger flow could have been erupted and not preserved.

\section{Mineral chemistry and assemblages}

In this section we present the petrology and chemistry of Therasia lavas and pumices younger than $\sim 39$ ka (i.e., flow 3), as well as the products of the Cape Riva eruption (Fig. 9). We exclude the lower Therasia andesite, which is significantly older, as well as the andesite of Oia. In so doing we focus on the effusive leaks of dacite during the build-up to the Cape Riva eruption.

\section{Therasia products}

Therasia dacites. The Therasia dacites have whole rock $\mathrm{SiO}_{2}$ contents of $64.6-68.7 \mathrm{wt} \%$ and $\mathrm{MgO}$ contents of 0.7-1.5 wt \%, with groundmass (i.e., melt) $\mathrm{SiO}_{2}$ contents of 64.7-69.1 wt \%. No systematic evolution of either whole rock or groundmass composition is observed with height in the lava succession (Fig. 7). The dacites contain 1-17 wt \% of phenocrysts (with a smallest dimension $>0.5 \mathrm{~mm}$ ) of plagioclase (75-85 vol\%), 2 pyroxenes (10-20\%, with opx $>$ cpx), Fe-Ti oxides (5-8 \%) and trace amounts of olivine. Apatite occurs as inclusions in orthopyroxene crystals. The glassy groundmass contains microlites of feldspar and Fe-Ti oxides. Plagioclase phenocrysts are normally zoned, with cores of $\mathrm{An}_{38-89}$ and rims of $\mathrm{An}_{39-51}$, and commonly contain multiple internal dissolution surfaces and sawtooth zoning. The rims are euhedral, and are compositionally similar to plagioclase microlites in the groundmass $\left(\mathrm{An}_{30-51}\right)$. Orthopyroxene phenocrysts are euhedral and unzoned, and have compositions of $\mathrm{Wo}_{3-4} \mathrm{En}_{54-60} \mathrm{Fs}_{36-42}$. Clinopyroxenes are also euhedral and 
unzoned, and their compositions are $\mathrm{Wo}_{39-42} \mathrm{En}_{36-43} \mathrm{Fs}_{15-22}$. Some phenocrysts occur as aggregates of multiple euhedral crystals with brown interstitial glass. Xenocrysts of calcic plagioclase $\left(\mathrm{An}_{60}\right.$ $\left.{ }_{89}\right)$ occur frequently in the dacites, along with more calcic clinopyroxenes $\left(\mathrm{Wo}_{47-50} \mathrm{En}_{30-44} \mathrm{Fs}_{8-20}\right)$. There are also fragments of sub-solidus olivine-bearing gabbro, with some olivines that have broken down to form pyroxene-magnetite symplectites. Fe-Ti oxides from three different dacitic pumice fall deposits within the Therasia sequence record magmatic temperatures of $875 \pm 5{ }^{\circ} \mathrm{C}$ at an $\mathrm{f}_{\mathrm{O} 2}$ of $-13.4 \pm 0.1,896 \pm 12{ }^{\circ} \mathrm{C}$ at an $\mathrm{f}_{\mathrm{O} 2}$ of $-12.7 \pm 0.3$, and $926 \pm 9{ }^{\circ} \mathrm{C}$ at an $\mathrm{f}_{\mathrm{O} 2}$ of $-11.4 \pm 0.2(2 \sigma$, where $\sigma$ is the standard error of the mean, Supplementary Table S3).

The similarity between phenocryst rims and groundmass microlite compositions suggests an equilibrium phenocryst rim assemblage in these lavas. Sawtooth zoning of plagioclase is interpreted as recording repeated recharge of the magmas by hotter magma during phenocryst growth. Glassbearing phenocryst clusters were probably derived from crystal mush of the reservoir margins.

Therasia mafic enclaves. Quenched basaltic (49.6-51.8 wt \% $\left.\mathrm{SiO}_{2} ; 5.4-8.6 \mathrm{wt} \% \mathrm{MgO}\right)$ enclaves $1-10 \mathrm{~cm}$ in diameter are found in flows 3 and 11 , where they make up $<1 \%$ of the erupted volume. They contain phenocrysts of plagioclase ( $\sim 55 \mathrm{vol} \%)$, pyroxenes $(\sim 35 \mathrm{vol} \%$, with cpx >> opx) and olivine ( $\sim 10$ vol\%) set in a glassy, diktytaxitic groundmass. Two populations of plagioclase phenocrysts with different core compositions, but similar rim compositions, are observed: (1) normally zoned crystals with cores of $\mathrm{An}_{83-91}$ and rims of $\mathrm{An}_{64-71}$; (2) reversely zoned crystals with cores of $\mathrm{An}_{51-61}$, separated by a sieve-textured zone from rims normally zoned from $\mathrm{An}_{82-86}$ to $\mathrm{An}_{64-71}$. Plagioclase in the groundmass is $\mathrm{An}_{32-42}$. Olivines are normally zoned from cores of $\mathrm{Fo}_{77-82}$ to rims of $\mathrm{Fo}_{53-60}$. Two clinopyroxene populations are found, although their textural relationships with the plagioclase populations are ambiguous. Both cpx populations are euhedral and unzoned, with compositions of (1) $\mathrm{Wo}_{43-46} \mathrm{En}_{42-46} \mathrm{Fs}_{10-12}$ and (2) $\mathrm{Wo}_{41-44} \mathrm{En}_{39-43} \mathrm{Fs}_{15-20}$. Rare orthopyroxenes with compositions of $\mathrm{Wo}_{3} \mathrm{En}_{67} \mathrm{Fs}_{30}$ also occur. 
The occurrence of two plagioclase populations with different core compositions, but similar, intermediate rim compositions is indicative of magma mixing. Plagioclases of population 1 are interpreted as derived from a basaltic melt, and those of population 2 from a more evolved melt. The cores of olivine crystals (molar $\mathrm{Mg} / \mathrm{Fe}=3.37-4.64$ ) are in equilibrium with the whole rock (i.e., basaltic) composition $(\mathrm{Mg} / \mathrm{Fe}=1.20)$, assuming a crystal-melt partition coefficient of between 0.26 and 0.36 (Roeder and Emslie 1970). The composition of population-2 clinopyroxenes is similar to that of the clinopyroxene phenocrysts in the dacite. The enclaves are interpreted as having formed by the inmixing of a small proportion of more evolved magma (possibly dacitic, containing population-2 plagioclase cores + population-2 $\mathrm{cpx}$ ) into a basalt (containing population1 plagioclase cores + olivine + population-1 cpx; Fig. 10). Mixing occurred long enough prior to eruption for plagioclase from the evolved component to partially melt (generating sieve texture), followed by overgrowth of equilibrium rim compositions on plagioclases from both populations.

Upper Therasia andesite. The upper Therasia andesite (60.5 wt \% $\left.\mathrm{SiO}_{2}, 2.6 \mathrm{wt} \% \mathrm{MgO}\right)$ contains $26 \mathrm{wt} \%$ of macroscopic crystals: plagioclase (75 vol\%), pyroxenes $(20 \%$, with opx $\approx$ cpx), Fe-Ti oxides ( $5 \%$ ) and trace amounts of olivine set in a glassy, 64 wt \% $\mathrm{SiO}_{2}$ groundmass containing microlites of plagioclase and magnetite. Three distinct populations of plagioclase are observed: (1) normally zoned crystals with cores of $\mathrm{An}_{83-89}$, and euhedral rims of $\mathrm{An}_{57-61}$; (2) crystals with cores of $\mathrm{An}_{53-60}$ separated by a sieve-textured zone from rims normally zoned from $\mathrm{An}_{75-87}$ to $\mathrm{An}_{55-70}$; (3) normally zoned crystals with cores as calcic as $\mathrm{An}_{76}$ and rims of $\mathrm{An}_{36-55}$. Rare olivines have cores of $\mathrm{Fo}_{80-83}$, and rims of $\mathrm{Fo}_{67-69}$. Orthopyroxenes have compositions of $\mathrm{Wo}_{3} \mathrm{En}_{57-}$ ${ }_{59} \mathrm{Fs}_{38-39}$, and clinopyroxenes have compositions of $\mathrm{Wo}_{39-42} \mathrm{En}_{40-43} \mathrm{Fs}_{15-20}$.

Plagioclase populations 1 and 2 texturally and compositionally resemble plagioclase populations 1 and 2 (respectively) in the basaltic enclaves; population 3 resembles plagioclase phenocrysts in the dacites. The olivine rims have a molar $\mathrm{Mg} / \mathrm{Fe}$ ratio of $1.99-2.22$, which is in, or close to, equilibrium with the groundmass $(\mathrm{Mg} / \mathrm{Fe}=0.76)$, assuming a partition coefficient of 
between 0.26 and 0.36 (Roeder and Emslie 1970); the cores have an $\mathrm{Mg} / \mathrm{Fe}$ ratio of 4.11-4.81 and grew in equilibrium with a basaltic melt. The two pyroxenes are indistinguishable from the same phases in the dacites. The upper Therasia andesite is interpreted as a hybrid magma formed by the mixing of the basalt (containing plagioclase of populations 1 and $2+$ olivine) represented by the enclaves, with typical Therasia dacite (containing population-3 plagioclase $+o p x+c p x)$. Mixing occurred long enough prior to eruption to permit physical homogenization of the resulting hybrid melt, but not long enough for crystals to grow rims in equilibrium with that melt, or for those from the dacite to be resorbed.

\section{Cape Riva products}

Cape Riva Dacite. Dacitic pumices of the Cape Riva eruption have whole rock compositions of 64-67 wt $\% \mathrm{SiO}_{2}$ and 1.0-1.9 wt $\% \mathrm{MgO}$, and interstitial glasses with 70-72 wt $\% \mathrm{SiO}_{2}$. Phenocryst phases and proportions are the same as in the Therasia dacites, with total contents ranging from 15 to $20 \mathrm{wt} \%$. Plagioclase phenocrysts are euhedral, with rims of $\mathrm{An}_{31-65}$, and cores as calcic as $\mathrm{An}_{70}$. As in the Therasia dacites, plagioclase phenocrysts in the Cape Riva dacite contain complex dissolution surfaces and saw tooth zoning. Rare xenocrysts of $\mathrm{An}_{70-96}$ also occur. Orthopyroxene phenocrysts have compositions of $\mathrm{Wo}_{3} \mathrm{En}_{52-68} \mathrm{Fs}_{45-29}$, and clinopyroxenes from $\mathrm{Wo}_{44} \mathrm{En}_{41} \mathrm{Fs}_{15}$ to $\mathrm{Wo}_{40} \mathrm{En}_{36} \mathrm{Fs}_{24}$. Touching Fe-Ti oxide pairs give temperatures of $879 \pm 15^{\circ} \mathrm{C}$ and $\mathrm{fO}_{2}$ of $-12.9 \pm 0.4$ (Cadoux et al. 2013).

Cape Riva mafic enclaves. Millimetre-sized quenched blebs of basaltic magma occur dispersed $(<<1 \%)$ through the Cape Riva dacite, and in banded pumices containing the dacite and andesite mingled together. They contain $\mathrm{An}_{90-96}$ plagioclase, $\mathrm{Fo}_{72-84}$ olivine, $\mathrm{Wo}_{41-44} \mathrm{En}_{36-}$ ${ }_{41} \mathrm{Fs}_{15-23} \mathrm{cpx}$ and rare $\mathrm{Wo}_{3} \mathrm{En}_{68} \mathrm{Fs}_{29}$ opx. The enclaves have micro-crenulated surface textures, and many have a single crystal or xenocrystic fragment at their centres. They are interpreted as small fragments of chilled basaltic magma. 
Cape Riva andesite. The Cape Riva andesitic scoria has 60-62 wt $\% \mathrm{SiO}_{2}$ and 3.2-2.5 wt\% $\mathrm{MgO}$; it contains $\sim 12 \mathrm{wt} \%$ macroscopic crystals of plagioclase, olivine, clinopyroxene and magnetite set in brown dacitic glass with $63.5 \mathrm{wt} \% \mathrm{SiO}_{2}$. The pure andesitic component (free of any in-mingled streaks of dacite) contains two populations of plagioclase: (1) a calcic population of $\mathrm{An}_{70-96}$, with a discrete population of euhedral, unzoned grains of $\mathrm{An}_{90-96}$, and (2) a less abundant population with cores up to $\mathrm{An}_{52}$ and rims of $\mathrm{An}_{30-40}$. Olivines are compositionally uniform $\left(\mathrm{Fo}_{84}\right)$. Augites occur sparsely as microphenocrysts of $\mathrm{Wo}_{40-41} \mathrm{En}_{41-43} \mathrm{Fs}_{19}$. No orthopyroxene has been observed.

The olivines and population-1 plagioclases in the andesite resemble phenocrysts present in the basaltic enclaves, whereas population-2 plagioclase resembles phenocrysts in the dacites. Genesis of the Cape Riva andesite is inferred to have involved the mixing of basaltic and dacitic magmas. Eruption occurred long after mixing for the hybrid glass to become homogeneous at the scale of the electron beam $(\sim 10 \mu \mathrm{m})$.

\section{Whole rock chemistry and mixing systematics}

Representative samples of each unit are shown in Table 3, and the complete dataset is presented in Supplementary Table S4. We have used a series of variation diagrams showing the whole rock compositions of the Therasia and Cape Riva magmas, plus those of the lavas of the Skaros shield (from Huijsmans 1985) to gain insight into the petrogenesis of the different magmas

(Figs 11 and 12). Typical fractionation trends for Santorini magmas are also shown (Mann 1983; Huijsmans 1985; Druitt et al. 1999).

Fig. 11 shows the variations of five key major oxides $\left(\mathrm{CaO}, \mathrm{MgO}, \mathrm{FeO}, \mathrm{TiO}_{2}, \mathrm{P}_{2} \mathrm{O}_{5}\right)$ and two strongly compatible trace elements $(\mathrm{Cr}$ and $\mathrm{Ni})$. On the plots of $\mathrm{CaO}$ and $\mathrm{MgO}$ (also $\mathrm{Na}_{2} \mathrm{O}, \mathrm{Al}_{2} \mathrm{O}_{3}$, $\mathrm{V}$ and Sc) on which typical fractionation trends are weakly curved, all the Therasia and Cape Riva 
magmas fall on, or close to, the fractionation trend. However, on the plots of $\mathrm{FeO}, \mathrm{TiO}_{2}, \mathrm{P}_{2} \mathrm{O}_{5}, \mathrm{Cr}$ and $\mathrm{Ni}$, on which the fractionation trends are strongly curved, the Cape Riva hybrid andesite falls systematically off the fractionation trend. This is what we would expect to see if it was generated by the mixing of mafic and silicic end-members. The upper Therasia hybrid andesite also falls off the fractionation trend on plots of $\mathrm{FeO}$ and $\mathrm{TiO}_{2}$, (it does not on the other plots because mixing occurred along the fractionation trend, not across it).

Mixing models using the 'PetroGraph' software (Petrelli et al. 2005) successfully reproduce the compositions of the upper Therasia and Cape Riva hybrid andesites (Table 4). In the case of the upper Therasia andesite, low $\mathrm{Cr}$ and $\mathrm{Ni}$ require the mafic end-member to also have low $\mathrm{Cr}$ and Ni. The relatively high $\mathrm{P}_{2} \mathrm{O}_{5}$, close to the fractionation trend, requires the silicic end-member to have a high $\mathrm{P}_{2} \mathrm{O}_{5}$ content, limiting it to a silica content of $64-67 \mathrm{wt} \%$. The upper Therasia andesite can be successfully reproduced by mixing $\sim 60 \mathrm{wt} \%$ of a typical Therasia dacite with $\sim 40 \mathrm{wt} \%$ of mafic magma with the same composition as a basaltic enclave (GS10-43) collected from the same flow (sum of the squares of the residuals of 0.16). The Cape Riva andesite has higher $\mathrm{Cr}$ and $\mathrm{Ni}$ than the upper Therasia andesite, requiring that the mafic end-member also has higher contents of these elements. The composition of the Cape Riva andesite can be modelled by mixing $\sim 60 \mathrm{wt} \%$ of Cape Riva dacite with $\sim 40 \mathrm{wt} \%$ of an average Skaros basalt (sum of the squares of the residuals of 0.14). However, the calculated Ni content is higher than that measured in the Cape Riva andesite, suggesting that the mafic endmember had lower Ni than the average Skaros basalt.

Despite their broadly similar compositions in terms of silica content and many other major and trace elements, most of the Therasia dacites are enriched in incompatible elements such as $\mathrm{K}, \mathrm{Rb}$ and $\mathrm{Zr}$ (also Nb, Ta, Th, Hf and LREE) compared to the Cape Riva dacite (Fig. 12). LREE are also more enriched in the Therasia dacites relative to the HREE. For example, the Therasia dacites have an average $\mathrm{La} / \mathrm{Yb}$ ratio of $5.91 \pm 0.16(2 \sigma)$, while the Cape Riva dacite has a ratio of $4.85 \pm 0.04$. Amongst the HFSE, $\mathrm{Nb}$ and Ta are more enriched than $\mathrm{Zr}$ and $\mathrm{Hf}$. The 23 analysed 
samples of Cape Riva pumice form a tight linear cluster on Fig. 12, showing that the magma was well mixed. All of the 11 analysed Therasia lavas younger than $\sim 39 \mathrm{ka}$, and most of the intercalated pumice horizons, similarly form a tight linear cluster (at higher incompatible contents than the Cape Riva, for a given $\mathrm{SiO}_{2}$ content). However, some of the Therasia pumices overlap with the Cape Riva field for some elements. Most prominent of these is the Cape Tripiti pumice (Fig. 5c), which lies in, or close to, the Cape Riva field for most incompatible elements except K, suggesting that the magma that fed the Cape Tripiti eruption had some chemical characteristics intermediate between the two groups of dacite.

The differences between the Therasia and Cape Riva dacites are also seen between the corresponding hybrid andesites of these two series. Despite having a similar $\mathrm{SiO}_{2}$ content, the upper Therasia hybrid andesite is enriched in incompatible elements compared to the Cape Riva hybrid andesite (e.g. $2.1 \mathrm{wt} \% \mathrm{~K}_{2} \mathrm{O}$ compared to $1.7 \mathrm{wt} \%$, respectively). Like the Therasia dacites, the Therasia andesite is also enriched in LREE relative to HREE, and enriched in $\mathrm{Nb}$ and Ta relative to $\mathrm{Zr}$ and $\mathrm{Hf}$ compared top the Cape Riva andesite. This is also reflected in the calculated mafic mixing end-members of the two hybrid andesites shown on Fig. 12, although the difference is subtle.

\section{Discussion}

\section{Origin of the magma series}

The Therasia and Cape Riva dacites have similar whole rock major element compositions (for all major elements except K), phenocryst assemblages, phenocryst rim compositions and Fe- $\mathrm{Ti}$ oxide temperatures, although the Cape Riva dacite has slightly more evolved interstitial melt. The main difference between the two magmas is that the Cape Riva dacite is depleted in incompatible 
elements compared to the Therasia dacite. The Cape Riva hybrid andesite is also incompatibledepleted relative to the upper Therasia hybrid andesite, and there are indications that the basaltic mixing end-members were similarly different.

Since the Therasia and Cape Riva magma series form parallel trends on incompatible element variation diagrams (Fig. 12), and have different LREE/HREE ratios, they cannot be related to each other simply by closed-system crystal fractionation schemes like those explored in previously published papers (Nicholls 1971; Mann 1983; Druitt et al. 1999). Neither can the Cape Riva dacite be generated by simple backmixing of Therasia dacite with an incompatible-depleted basalt, since mixing would displace the silicic compositions almost parallel to the compositional trends rather than perpendicular to them. Crustal contamination of Therasia dacite to produce Cape Riva dacite is also unlikely, as this would be expected to increase incompatible element concentrations, not decrease them (Barton et al. 1983; Druitt et al. 1999). Moreover, the two dacite types have very similar whole-rock ${ }^{87} \mathrm{Sr} /{ }^{86} \mathrm{Sr}$ ratios $(0.7050$ and 0.7049 respectively; Briqueu et al. 1986; Druitt et al. 1999; Zellmer et al. 2000), ruling out a significant difference in the extent of upper crustal contamination. The Therasia and Cape Riva magma series (basalt, dacite and hybrid andesite in each case) represent two fundamentally distinct magma batches that cannot be related to each other in any simple way by shallow-level processes.

This conclusion is supported by comparison of the two magma series with longerterm geochemical trends at Santorini (Huijsmans 1985; Huijsmans et al. 1988; Druitt et al. 1999). The same incompatible elements have decreased progressively in Santorini magmas over the last $530 \mathrm{ka}$, such that the lavas of the historical Kameni Volcano are the most incompatible-depleted (Fig. 12). The difference between the (older) Therasia and (younger) Cape Riva series represents one step in this longer-term evolution. The magnitude of the decrease is similar for most incompatible elements, so that the ratios between them (e.g. $\mathrm{K} / \mathrm{Zr}, \mathrm{Rb} / \mathrm{Zr}, \mathrm{Rb} / \mathrm{La}$ ) have remained approximately constant with time. However, the LREE have become depleted relative to HREE, a 
change that is also apparent between Cape Riva and Therasia (Fig. 12d). Similar changes also occur between different high field strength elements: $\mathrm{Nb}$ and Ta concentrations drop faster than those of $\mathrm{Zr}$ and Hf. Progressive depletion in $\mathrm{K}$ and other incompatible elements with time has also occurred at other centres in the Aegean region (Francalanci et al. 2005). A decrease in the extent of crustal contamination with time, as might be expected from the progressive sealing-off of ascending magmas from the crust, is not tenable; there is no evidence for a decrease in the ${ }^{87} \mathrm{Sr} /{ }^{86} \mathrm{Sr}$ ratio with time at Santorini. Isotopic signatures fluctuate with time (Barton et al. 1983; Briqueu et al. 1986; Druitt et al. 1999; Martin et al. 2010), and some young melts are amongst the most radiogenic in the history of the volcano (Vaggelli et al. 2009; Martin et al. 2010). Incompatible trace element contents and isotopic signatures at Santorini are decoupled, ruling out a simple common origin. A more likely explanation for the observed trends lies in the nature of the mantle sources of the parental basalts feeding the volcanic system. Possibilities include an increase with time in the degree of source depletion, an increase of source melt fraction, or a decrease in degree of source metasomatism by slab-derived fluids or melts. All of these mechanisms could potentially account for basaltic parents with decreasing incompatible element contents with time (Huijsmans et al. 1988; Clift and Blusztajn 1999; Zellmer et al. 2000; Francalanci et al. 2005; Bailey et al. 2009). A mantle origin is supported by the recent discovery at Santorini of multiple co-existing basalt types with different trace element and isotopic signatures (Bailey et al. 2009; Vaggelli et al. 2009). Changing proportions of different parental basalts that ascend into the crust, where they mix and differentiate at between 4 and $2 \mathrm{~kb}$ to intermediate and silicic compositions (Andújar et al. 2010; Cadoux et al. 2013), may account for the observed temporal variations of trace element chemistry. Irrespective of the exact explanation, our results demonstrate the availability of chemically distinct batches of silicic magma within the crustal plumbing system beneath Santorini, as has been demonstrated previously for basalts (Bailey et al. 2009). 


\section{Reconstruction of events leading up to the Cape Riva eruption}

Construction of the $\sim 12 \mathrm{~km}^{3}$ basaltic-to-andesitic Skaros shield between 67 and $54 \mathrm{ka}$ represented a period where the eruption rate was close to the average for Santorini $\left(\sim 1 \mathrm{~km}^{3} \cdot \mathrm{ky}^{-1}\right.$; Druitt et al. 1999). The Skaros period culminated at 54 ka in the Upper Scoria 2 explosive eruption. Following Upper Scoria 2, the system stagnated and entered a $\sim 15$ ky-long period of near-repose until effusive activity resumed at about $39 \mathrm{ka}$. Only two lava flows are preserved in the cliffs of Therasia from this period: the $\sim 48$ ka lower Therasia andesite (flows 1 and 24 ) and an inaccessible flow (flow 2) immediately above it. The andesite of Oia could also belong to this period; it is chemically very similar to Upper Scoria 2 and could be residual magma from that eruption. This period of reduced activity, during which the apparent eruption rate based on preserved products was very low $\left(<0.1 \mathrm{~km}^{3} \cdot \mathrm{ky}^{-1}\right)$, is marked by the development of thick palaeosols.

Any mantle-derived basalt injected into the crust during this period must have been trapped at depth, perhaps due to the stress imposed by the high Skaros edifice (Pinel and Jaupart 2000). Accumulation of heat from prolonged, deep intrusion probably generated silicic melt by a combination of fractional crystallization, partial melting of crustal rocks and defrosting of extant mushy intrusions (Mann 1983; Barton et al. 1983; Huijsmans 1985; Huijsmans and Barton 1989; Druitt et al. 1999). Then, between 39 and $25 \mathrm{ka}$, a chemically and thermally $\left(895-925^{\circ} \mathrm{C}\right)$ monotonous series of dacites (the Therasia dome complex) was extruded from the summit of Skaros and from dykes on its western flank. The lack of any systematic variation of whole rock or groundmass (i.e., melt) composition with time during this period (Fig. 7) suggests thermal buffering of the crustal storage region by an approximate balance of heat input, heat output and latent heat of crystallisation. The mean eruption rate during construction of the Therasia dome complex was very approximately $0.1-0.2 \mathrm{~km}^{3} \cdot \mathrm{ky}^{-1}$ : lower than the long-term average on Santorini $\left(\sim 1 \mathrm{~km}^{3} \cdot \mathrm{ky}^{-1}\right)$, but higher than that during the preceding repose period. Towards the end of the Therasia activity, lava 
extrusion became increasingly punctuated by explosive activity. Throughout most of this $15 \mathrm{ky}$ period, the eruptions tapped typical Therasia-type dacite. However, the 26 ka Cape Tripiti eruption tapped dacite with some incompatible trace element contents intermediate between those of Therasia and Cape Riva. Any basaltic magma intruded beneath the summit region over the $15 \mathrm{ky}$ was unable to reach the surface, except as rare quenched enclaves of dacite-contaminated olivine basalt. Towards the end of the period, basalt mixed with dacite in approximately equal proportions, forming the upper Therasia hybrid andesite.

Following extrusion of the last Therasia lava, no more than 2,800 $\pm 1,400$ years elapsed before the $21.8 \pm 0.4 \mathrm{ka}$ Cape Riva eruption took place. At least $10 \mathrm{~km}^{3}$ of $880^{\circ} \mathrm{C}$ Cape Riva dacite, poorer in incompatible elements, was then erupted as Plinian fallout and pyroclastic flows. The eruption also discharged a small quantity $\left(<<1 \mathrm{~km}^{3}\right)$ of hybrid andesite formed by the mixing of olivine basalt and incompatible-depleted dacite in sub-equal proportions, and the Skaros-Therasia edifice collapsed (Druitt et al. 1999).

\section{Constraints on magma reservoir development}

The Therasia dacites have been previously interpreted as 'precursory leaks' from the growing Cape Riva magma body (Druitt 1985; Bacon 1985). Precursory leaks of silicic magma from diffuse vents prior to caldera-forming eruptions are believed to record the prolonged, incremental growth of large crustal magma reservoirs (Bacon 1985). For example, leaks of rhyodacite at Mount Mazama (Crater Lake, Oregon) bear witness to the progressive growth, over about 20,000 years, of the magma body that was discharged 6,850 years ago (Bacon 1985; Bacon and Lanphere 2006). However, the Therasia lavas cannot simply be leaks from a single, growing Cape Riva reservoir, because they represent a chemically different magma batch. 
One possibility is that the two dacite types were stored in separate, long-lived reservoirs that coexisted in the upper crust, perhaps for much of the 30 ky since Upper Scoria 2. The Therasia eruptions would have been fed from one or more small reservoir(s), and the Cape Riva eruption from another, larger reservoir. The Cape Tripiti pumice, with its intermediate chemical character, might have resulted from a temporary connection between the two reservoirs. However, field and phase equilibria data provide quite stringent constraints on the possible locations of the two reservoirs in such a model. First, the vents that fed the Therasia lavas lay within the area that subsequently collapsed to form the Cape Riva caldera (Druitt 1985, 2013; Druitt and Francaviglia 1992), showing that the reservoirs were geographically coincident. Second, the similarities in whole rock major element composition, phenocryst assemblage, phenocryst rim compositions and FeTi oxide temperatures, show that the Therasia dacites must have been stored immediately prior to eruption at a pressure $(2 \pm 0.5 \mathrm{~kb}$, equivalent to $8 \pm 2 \mathrm{~km})$ similar to that determined experimentally for the Cape Riva dacite by Cadoux et al (2013). The two reservoirs must therefore have been situated within the $\sim 4 \mathrm{~km}$ vertical distance represented by the $\pm 0.5 \mathrm{~kb}$ uncertainty on the pressure. Moreover, this uncertainty is on the absolute pressure, not on the relative pressure difference between the two dacite types. It is difficult to see how two magma reservoirs within this confined space could remain largely isolated over many thousands of years. We cannot rule out this model, but it raises problems that are hard to surmount.

Our preferred interpretation is that the Therasia and Cape Riva magma batches were emplaced sequentially into the upper crust beneath the summit of the volcano, the first then being partially, or wholly, flushed out by the arrival of the second. In this model the $15 \mathrm{ky}$ of Therasia activity was fed either from a single long-lived, melt-dominated reservoir or by the ascent, partial eruption and rapid freezing of multiple melt packets (e.g., Zellmer et al. 2003). At 26 ka the system may have been replenished by incompatible-depleted dacite, which mixed with Therasia dacite and was discharged as the Cape Tripiti Pumice. The subsequent return to eruption of 'pure' Therasia 
dacite suggests that if a discrete Cape Riva reservoir already existed below the summit at this time, it had probably not yet reached its full size. Following extrusion of the last Therasia lava flow, the input of incompatible-depleted dacite continued, and perhaps accelerated, during the $<2,800$ $\pm 1,400$ y preceding the Cape Riva eruption. The new input magma mixed with any remaining Therasia magma to generate the dacite that subsequently discharged during the Cape Riva eruption. This may have had the composition of pure Cape Riva dacite, or may have been a dacite even poorer in incompatibles (e.g. Kameni-like dacite; Fig. 12). Amalgamation and homogenization of the different magma batches resulted in the formation of a single, contiguous reservoir.

Assuming injection of most of the $>10 \mathrm{~km}^{3}$ of Cape Riva magma in $<2800$ y yields a timeaveraged supply rate of $>0.004 \pm 0.002 \mathrm{~km}^{3} \cdot \mathrm{y}^{-1}$, although the peak value may have been much higher. For comparison, the mean accumulation rate estimated over the $1600 \mathrm{y}$ to prior the Oruanui eruption has been estimated as $>0.33 \mathrm{~km}^{3} \cdot \mathrm{y}^{-1}$, culminating in values of $\sim 1 \mathrm{~km}^{3} \cdot \mathrm{y}^{-1}$ (Wilson and Charlier 2009; Allan et al. 2013). A late-stage growth spurt of the Minoan magma reservoir has been estimated as $>0.05 \mathrm{~km}^{3} \cdot \mathrm{y}^{-1}$ (Druitt et al. 2012). Intrusion rates comparable to, or higher than, that estimated for the Cape Riva are implied by measured deformation rates at silicic volcanoes such as Uturuncu ( 0.01 km³. $\mathrm{y}^{-1}$; Pritchard and Simons 2004; Sparks et al. 2008), Kameni $\left(\sim 0.01 \mathrm{~km}^{3} . \mathrm{y}^{-1}\right.$; Parks et al. 2012), Yellowstone $\left(0.1 \mathrm{~km}^{3} \cdot \mathrm{y}^{-1}\right.$; Chang et al. 2010), and Lazufre $\left(\sim 0.01 \mathrm{~km}^{3} . \mathrm{y}^{-1}\right.$; Froger et al. 2007; Ruch et al. 2009).

Rapid intrusion of the Cape Riva dacite into the upper crust would have favoured runaway growth of a melt-dominated magma reservoir (Annen 2009; Schöpa and Annen 2013; Gelman et al. 2013). Driving mechanisms for magma ascent may have included increased basaltic flux from the mantle, tectonic forces, or gravitational instability of crustal magma storage regions. Possible evidence of increased basaltic flux is provided by the production of hybrid andesites (formed by mixing of basalt and dacite in approximately equal proportions) in the few thousand years prior to the Cape Riva eruption, as well as in the Cape Riva reservoir itself. Pressurization of the upper 
crustal plumbing system by sustained, high-flux injection of dacite and basalt may have triggered the transition from prolonged, largely effusive activity to catastrophic explosive eruption and caldera collapse.

\section{Conclusions}

We have combined field, high-resolution radiometric, petrological and geochemical approaches in a study of the evolution of the crustal magma plumbing system of Santorini prior to a silicic caldera-forming eruption. The main conclusions are listed below.

1. Between $39 \mathrm{ka}$ and $25 \mathrm{ka}$, a sequence of compositionally (65-68 wt $\left.\% \mathrm{SiO}_{2}\right)$ and thermally $\left(895-925{ }^{\circ} \mathrm{C}\right.$ ) monotonous dacitic lavas leaked out to form the $\sim 2 \mathrm{~km}^{3}$ Therasia dome complex across the summit and western flank of the high, extant Skaros lava shield. Pyroclastic units interbedded with the lavas towards the top of the sequence record increasing explosivity of the system towards the end of this period. One prominent pumice fall deposit within the Therasia complex probably correlates with the $26 \mathrm{ka}$ Y-4 ash layer observed in deep-sea sediments SE of Santorini. Following a pause in activity no longer than $2,800 \pm 1,400 \mathrm{ky}$, the $21.8 \pm 0.4 \mathrm{ka}$ Cape Riva explosive eruption discharged $>10 \mathrm{~km}^{3}$ of $880^{\circ} \mathrm{C}$ dacite, and collapsed the Skaros shield.

2. The Therasia and Cape Riva dacites are similar in most major elements, but the Cape Riva dacite has lower contents of $\mathrm{K}$ and incompatible trace elements (e.g., Rb, Zr, Th, LREE) than the Therasia dacites at a given silica content. This decrease in incompatibles that took place at $21.8 \mathrm{ka}$ is one step in the well-documented longer-term decrease in incompatible elements with time observed at Santorini over the last $530 \mathrm{ka}$. The Therasia and Cape Riva dacites represent distinct magma batches that are unrelated by shallow-level processes. 
3. Given that the source vents for the Therasia and Cape Riva dacites were geographically coincident, and that the reservoir depths estimated from phase equilibria were similar, accumulation of most of the Cape Riva magma in the upper crust probably took place within the $2,800 \pm 1,400$ y period between the last Therasia eruption and the Cape Riva. This would have required a time-averaged magma accumulation rate in excess of $0.004 \pm 0.002 \mathrm{~km}^{3} \mathrm{y}^{-1}$

4. Discharge of basaltic magma during this time period is limited to $<<1 \%$ quenched enclaves of olivine basalt in some Therasia lavas and in Cape Riva pumice. However, hybrid andesite magmas formed by the mixing of olivine basalt and dacite in approximately equal proportions were erupted as lava towards the end of the Therasia, and as scoria in the Cape Riva eruption. These hybrids may record an increased influx of basalt into the upper crust over the several thousands of years leading up to the Cape Riva eruption. Increased basaltic flux may have played a role in the rapid accumulation of incompatible-depleted Cape Riva magma beneath the summit of Skaros Volcano prior to its 21.8 ka eruption.

5. Pressurization of the upper crustal plumbing system by sustained, high-flux injection of dacite and basalt may have triggered the transition from prolonged, largely effusive activity (Therasia) to catastrophic explosive eruption and caldera collapse (Cape Riva).

\section{Acknowledgments}

We thank M Benbakkar and C Chauvel for providing major element and trace element analyses, respectively, and J-L Devidal for help with the electron microprobe. J Keller kindly drew our attention to the Y-4 deep-sea ash layer. E Klemetti, D Morgan and G Zellmer provided helpful reviews, and F Costa commented on an earlier version of the manuscript. The work was carried out in the framework of the project 'Storage and Mixing at Santorini' financed by the French 
Agence National de Recherche [ANR-08-BLAN-0249-01]. GN Fabbro was funded by the Région

d'Auvergne. This is Laboratory of Excellence ClerVolc contribution number 76.

\section{References}

Allan ASR, Morgan DJ, Wilson CJN, Millet M-A (2013) From mush to eruption in centuries: assembly of the super-sized Oruanui magma body. Contrib Miner Pet 166:143-164. doi:10.1007/s00410-013-0869-2

Andersen DJ, Lindsley DH (1985) New (and final!) models for the Ti-magnetite/ilmenite geothermometer and oxygen barometer. Eos Trans Am Geophys Union 66:416.

Andújar, J., Scaillet, B., Pichavant, M., Druitt, T.H., 2010. Differentiation conditions of a basaltic magma from Santorini and its bearing on andesitic/dacitic magma production. $2010 \mathrm{AGU}$ Fall Meeting, San Francisco, Abstract V43A-2354.

Annen C (2009) From plutons to magma chambers: Thermal constraints on the accumulation of eruptible silicic magma in the upper crust. Earth Planet Sci Lett 284:409-416. doi:10.1016/ j.epsl.2009.05.006

Annen C, Blundy JD, Sparks RSJ (2006) The genesis of intermediate and silicic magmas in deep crustal hot zones. J Pet 47:505 -539. doi:10.1093/petrology/egi084

Asku AE, Jenner G, Hiscott RN, İşler EB (2008) Occurrence, stratigraphy and geochemistry of late Quaternary tephra layers in the Aegean Sea and the Marmara Sea. Mar Geol 252:174-192. doi:10.1016/j.margeo.2008.04.004

Bachmann O, Bergantz G (2008) The magma reservoirs that feed supereruptions. Elements 4:1721. doi:10.2113/GSELEMENTS.4.1.17

Bachmann O, Bergantz GW (2004) On the origin of crystal-poor rhyolites: extracted from batholithic crystal mushes. J Pet 45:1565-1582. doi:10.1093/petrology/egh019

Bachmann O, Bergantz GW (2006) Gas percolation in upper-crustal silicic crystal mushes as a mechanism for upward heat advection and rejuvenation of near-solidus magma bodies. $\mathrm{J}$ Volcanol Geotherm Res 149:85-102. doi:10.1016/j.jvolgeores.2005.06.002

Bacon CR (1985) Implications of silicic vent patterns for the presence of large crustal magma chambers. J Geophys Res 90:11243-11252. doi:10.1029/JB090iB13p11243

Bacon CR, Lanphere MA (2006) Eruptive history and geochronology of Mount Mazama and the Crater Lake region, Oregon. Geol Soc Am Bull 118:1331-1359. doi:10.1130/B25906.1

Bailey JC, Jensen ES, Hansen A, Kann ADJ, Kann K (2009) Formation of heterogeneous magmatic series beneath North Santorini, South Aegean island arc. Lithos 110:20-36. doi:10.1016/ j.lithos.2008.12.002 
Barton M, Salters VJM, Huijsmans JPP (1983) Sr isotope and trace element evidence for the role of continental crust in calc-alkaline volcanism on Santorini and Milos, Aegean Sea, Greece. Earth Planet Sci Lett 63:273-291. doi:10.1016/0012-821X(83)90042-0

Blundy J, Cashman K (2008) Petrologic reconstruction of magmatic system variables and processes. Rev Miner Geochem 69:179-239. doi:10.2138/rmg.2008.69.6

Briqueu L, Javoy M, Lancelot JR, Tatsumoto M (1986) Isotope geochemistry of recent magmatism in the Aegean arc: Sr, Nd, Hf, and O isotopic ratios in the lavas of Milos and Santorinigeodynamic implications. Earth Planet Sci Lett 80:41-54. doi:10.1016/0012-821X(86) 90018-X

Brown M, Solar GS (1998) Shear-zone systems and melts: feedback relations and self-organization in orogenic belts. J Struct Geol 20:211-227. doi:10.1016/S0191-8141(97)00068-0

Brown SJA, Fletcher IR (1999) SHRIMP U-Pb dating of the preeruption growth history of zircons from the $340 \mathrm{ka}$ Whakamaru Ignimbrite, New Zealand: Evidence for $>250$ k.y. magma residence times. Geology 27:1035-1038. doi:10.1130/0091-7613(1999) 027<1035:SUPDOT>2.3.CO;2

Burgisser A, Bergantz GW (2011) A rapid mechanism to remobilize and homogenize highly crystalline magma bodies. Nature 471:212-215. doi:10.1038/nature09799

Cadoux A, Scaillet B, Druitt TH, Deloule E (2013) Magma storage conditions of large Plinian eruptions of Santorini Volcano. J Pet (Submitted).

Chang W-L, Smith RB, Farrell J, Puskas CM (2010) An extraordinary episode of Yellowstone caldera uplift, 2004-2010, from GPS and InSAR observations. Geophys Res Lett 37:L23302. doi:201010.1029/2010GL045451

Charlier BLA, Wilson CJN, Lowenstern JB, Blake S, Van Calsteren PW, Davidson JP (2005) Magma generation at a large, hyperactive silicic volcano (Taupo, New Zealand) revealed by U-Th and U-Pb systematics in zircons. J Pet 46:3-32. doi:10.1093/petrology/egh060

Clift P, Blusztajn J (1999) The trace-element characteristics of Aegean and Aeolian volcanic arc marine tephra. J Volcanol Geotherm Res 92:321-347. doi:16/S0377-0273(99)00059-1

Costa F (2008) Residence times of silicic magmas associated with calderas. In: Gottsmann J, Martí J (eds) Caldera Volcanism Anal. Model. Response. Elsevier, pp 1-55

Cottrell E, Gardner JE, Rutherford MJ (1999) Petrologic and experimental evidence for the movement and heating of the pre-eruptive Minoan rhyodacite (Santorini, Greece). Contrib Miner Pet 135:315-331. doi:10.1007/s004100050514

Druitt TH (1985) Vent evolution and lag breccia formation during the Cape Riva eruption of Santorini, Greece. J Geol 93:439-454.

Druitt TH (1983) Explosive Volcanism on Santorini, Greece. Ph.D., University of Cambridge

Druitt TH (2013) New insights into the initiation and venting of the Bronze-Age eruption of Santorini, from component analysis. Bull Volcanol (Submitted). 
Druitt TH, Costa F, Deloule E, Dungan M, Scaillet B (2012) Decadal to monthly timescales of magma transfer and reservoir growth at a caldera volcano. Nature 482:77-80. doi:10.1038/ nature 10706

Druitt TH, Edwards L, Mellors RM, et al. (1999) Santorini Volcano. Geological Society, London, Memoirs 19

Druitt TH, Francaviglia V (1992) Caldera formation on Santorini and the physiography of the islands in the late Bronze Age. Bull Volcanol 54:484-493. doi:10.1007/BF00301394

Druitt TH, Sparks RSJ (1982) A proximal ignimbrite breccia facies on Santorini, Greece. J Volcanol Geotherm Res 13:147-171. doi:16/0377-0273(82)90025-7

Eriksen U, Friedrich WL, Buchardt B, Tauber H, Thomsen MS (1990) The Stronghyle caldera: geological, palaeontological and stable isotope evidence from radiocarbon dated stromatolites from Santorini. In: Hardy DA, Keller J, Galanopoulos VP, Flemming NC, Druitt TH (eds) Thera Aegean World III. The Thera Foundation, London, pp 139-150

Fairbanks RG, Mortlock RA, Chiu T-C, Cao L, Kaplan A, Guilderson TP, Fairbanks TW, Bloom AL, Grootes PM, Nadeau M-J (2005) Radiocarbon calibration curve spanning 0 to 50,000 years BP based on paired ${ }^{230} \mathrm{Th} /{ }^{234} \mathrm{U} /{ }^{238} \mathrm{U}$ and ${ }^{14} \mathrm{C}$ dates on pristine corals. Quat Sci Rev 24:1781-1796. doi:10.1016/j.quascirev.2005.04.007

Federman AN, Carey SN (1980) Electron microprobe correlation of tephra layers from Eastern Mediterranean abyssal sediments and the Island of Santorini. Quat Res 13:160-171. doi:10.1016/0033-5894(80)90026-5

Francalanci L, Vougioukalakis GE, Perini G, Manetti P (2005) A West-East traverse along the magmatism of the south Aegean volcanic arc in the light of volcanological, chemical and isotope data. In: Fytikas M, Vougioukalakis GE (eds) The South Aegean active volcaninc arc: present knowledge and future perspectives. Developments in Volcanology, Elsevier, pp $65-111$

Froger J-L, Remy D, Bonvalot S, Legrand D (2007) Two scales of inflation at Lastarria-Cordon del Azufre volcanic complex, central Andes, revealed from ASAR-ENVISAT interferometric data. Earth Planet Sci Lett 255:148-163. doi:10.1016/j.epsl.2006.12.012

Gansecki, C.A., Mahood, G.A., McWilliams, M.O., 1996. ${ }^{40} \mathrm{Ar} /{ }^{39} \mathrm{Ar}$ geochronology of rhyolites erupted following collapse of the Yellowstone caldera, Yellowstone Plateau volcanic field: implications for crustal contamination. Earth and Planetary Science Letters 142, 91-107.

Gelman SE, Gutiérrez FJ, Bachmann O (2013) On the longevity of large upper crustal silicic magma reservoirs. Geology 41:759-762. doi:10.1130/G34241.1

Gualda GAR, Pamukcu AS, Ghiorso MS, Anderson AT, Sutton SR, Rivers ML (2012) Timescales of Quartz Crystallization and the Longevity of the Bishop Giant Magma Body. PLOS One 7:e37492. doi:10.1371/journal.pone.0037492

Heiken G, McCoy F (1984) Caldera development during the Minoan eruption, Thira, Cyclades, Greece. J Geophys Res 89:8441-8462. doi:10.1029/JB089iB10p08441 
Hildreth W (1981) Gradients in silicic magma chambers: Implications for lithospheric magmatism. J Geophys Res Solid Earth 86:10153-10192. doi:10.1029/JB086iB11p10153

Hildreth W, Moorbath S (1988) Crustal contributions to arc magmatism in the Andes of Central Chile. Contrib Miner Pet 98:455-489. doi:10.1007/BF00372365

Hildreth W, Wilson CJN (2007) Compositional zoning of the Bishop Tuff. J Pet 48:951-999. doi:10.1093/petrology/egm007

Huber C, Bachmann O, Dufek J (2011) Thermo-mechanical reactivation of locked crystal mushes: Melting-induced internal fracturing and assimilation processes in magmas. Earth Planet Sci Lett 304:443-454. doi:10.1016/j.eps1.2011.02.022

Huijsmans, J.P.P., 1985. Calc-alkaline lavas from the volcanic complex of Santorini, Aegean Sea, Greece. A petrological and stratigraphical study. (Ph.D.). Rijksuniversiteit te Utrecht.

Huijsmans JPP, Barton M (1989) Polybaric geochemical evolution of two shield volcanoes from Santorini, Aegean Sea, Greece: evidence for zoned magma chambers from cyclic compositional variations. J Pet 30:583-625. doi:10.1093/petrology/30.3.583

Huijsmans JPP, Barton M, Salters VJM (1988) Geochemistry and evolution of the calc-alkaline volcanic complex of Santorini, Aegean Sea, Greece. J Volcanol Geotherm Res 34:283-306. doi:10.1016/0377-0273(88)90039-X

Karagianni EE, Papazachos CB, Panagiotopoulos DG, Suhadolc P, Vuan A, Panza GF (2004) Shear velocity structure in the Aegean area obtained by inversion of Rayleigh waves. Geophys J Int 160:127-143. doi:10.1111/j.1365-246X.2005.02354.x

Keller J, Ryan WBF, Ninkovich D, Altherr R (1978) Explosive volcanic activity in the Mediterranean over the past 200,000 yr as recorded in deep-sea sediments. Geol Soc Am Bull 89:591-604. doi:10.1130/0016-7606(1978)89<591:EVAITM>2.0.CO;2

Klemetti EW, Deering CD, Cooper KM, Roeske SM (2011) Magmatic perturbations in the Okataina Volcanic Complex, New Zealand at thousand-year timescales recorded in single zircon crystals. Earth Planet Sci Lett 305:185-194. doi:10.1016/j.eps1.2011.02.054

Konstantinou KI (2010) Crustal rheology of the Santorini-Amorgos zone: Implications for the nucleation depth and rupture extent of the 9 July 1956 Amorgos earthquake, southern Aegean. J Geodyn 50:400-409. doi:10.1016/j.jog.2010.05.002

Lepage LD (2003) ILMAT: an Excel worksheet for ilmenite-magnetite geothermometry and geobarometry. Comput Geosci 29:673-678. doi:10.1016/S0098-3004(03)00042-6

Lindsay JM, Schmitt AK, Trumbull RB, Silva SLD, Siebel W, Emmermann R (2001) Magmatic evolution of the La Pacana caldera system, central Andes, Chile: compositional variation of two cogenetic, large-volume felsic ignimbrites. J Pet 42:459-486. doi:10.1093/petrology/ 42.3.459

Mann AC (1983) Trace element geochemistry of high alumina basalt-andesite-dacite-rhyodacite lavas of the Main Volcanic Series of Santorini Volcano, Greece. Contrib Miner Pet 84:4357. doi:10.1007/BF01132329 
Manning SW, Ramsey CB, Kutschera W, Higham T, Kromer B, Steier P, Wild EM (2006) Chronology for the Aegean Late Bronze Age 1700-1400 B.C. Science 312:565 -569. doi:10.1126/science.1125682

Margari V, Pyle DM, Bryant C, Gibbard PL (2007) Mediterranean tephra stratigraphy revisited: Results from a long terrestrial sequence on Lesvos Island, Greece. J Volcanol Geotherm Res 163:34-54. doi:10.1016/j.jvolgeores.2007.02.002

Martin, V.M., 2005. Geochemical and textural analysis of mafic enclaves from Nea Kameni, Santorini, Greece (Ph.D.). University of Cambridge.

Martin VM, Davidson J, Morgan D, Jerram DA (2010) Using the Sr isotope compositions of feldspars and glass to distinguish magma system components and dynamics. Geology 38:539-542. doi:10.1130/G30758.1

Mason BG, Pyle DM, Oppenheimer C (2004) The size and frequency of the largest explosive eruptions on Earth. Bull Volcanol 66:735-748. doi:10.1007/s00445-004-0355-9

McKenzie D (1985) The extraction of magma from the crust and mantle. Earth Planet Sci Lett 74:81-91. doi:10.1016/0012-821X(85)90168-2

Mellors RA, Sparks RSJ (1991) Spatter-rich pyroclastic flow deposits on Santorini, Greece. Bull Volcanol 53:327-342. doi:10.1007/BF00280225

Miller CF, Wark DA (2008) Supervolcanoes and their explosive supereruptions. Elements 4:11-15. doi:10.2113/GSELEMENTS.4.1.11

Narcisi B, Vezzoli L (1999) Quaternary stratigraphy of distal tephra layers in the Mediterranean-an overview. Glob Planet Change 21:31-50. doi:10.1016/S0921-8181(99)00006-5

Nicholls IA (1971) Petrology of Santorini Volcano, Cyclades, Greece. J Pet 12:67-119. doi:10.1093/petrology/12.1.67

Nocquet J-M (2012) Present-day kinematics of the Mediterranean: A comprehensive overview of GPS results. Tectonophys 579:220-242. doi:10.1016/j.tecto.2012.03.037

Papazachos BC, Karakostas VG, Papazachos CB, Scordilis EM (2000) The geometry of the Wadati-Benioff zone and lithospheric kinematics in the Hellenic arc. Tectonophys 319:275300. doi:10.1016/S0040-1951(99)00299-1

Parks MM, Biggs J, England P, Mather TA, Nomikou P, Palamartchouk K, Papanikolaou X, Paradissis D, Parsons B, Pyle DM, Raptakis C, Zacharis V (2012) Evolution of Santorini Volcano dominated by episodic and rapid fluxes of melt from depth. Nat Geosci 5:749-754. doi:10.1038/ngeo1562

Petrelli M, Poli G, Perugini D, Peccerillo A (2005) PetroGraph: A new software to visualize, model, and present geochemical data in igneous petrology. Geochem Geophys Geosystems 6:Q07011. doi:10.1029/2005GC000932

Pichler H, Friedrich W (1976) Radiocarbon dates of Santorini volcanics. Nature 262:373-374. doi:10.1038/262373a0 
Le Pichon X, Angelier J (1979) The Hellenic arc and trench system: A key to the neotectonic evolution of the eastern Mediterranean area. Tectonophys 60:1-42. doi:10.1016/00401951(79)90131-8

Pinel V, Jaupart C (2000) The effect of edifice load on magma ascent beneath a volcano. Philos Trans R Soc Lond Ser Math Phys Eng Sci 358:1515-1532. doi:10.1098/rsta.2000.0601

Pritchard ME, Simons M (2004) An InSAR-based survey of volcanic deformation in the central Andes. Geochem Geophys Geosystems 5:Q02002. doi:10.1029/2003GC000610

Pyle DM (1990) New estimates for the volume of the Minoan eruption. In: Hardy DA, Keller J, Galanopoulos VP, Flemming NC, Druitt TH (eds) Thera Aegean World III. The Thera Foundation, London, pp 113-121

Pyle DM, Elliott JR (2006) Quantitative morphology, recent evolution, and future activity of the Kameni Islands volcano, Santorini, Greece. Geosph 2:253-268. doi:10.1130/GES00028.1

Rasband WS (1997) ImageJ http://rsb.info.nih.gov/ij/ Accessed 18 Feb 2011

Renne PR, Balco G, Ludwig KR, Mundil R, Min K (2011) Response to the comment by W.H. Schwarz et al. on "Joint determination of ${ }^{40} \mathrm{~K}$ decay constants and ${ }^{40} \mathrm{Ar} * /{ }^{40} \mathrm{~K}$ for the Fish Canyon sanidine standard, and improved accuracy for ${ }^{40} \mathrm{Ar} /{ }^{39} \mathrm{Ar}$ geochronology" by P.R. Renne et al. (2010). Geochim Cosmochim Act 75:5097-5100. doi:10.1016/ j.gca.2011.06.021

Renne PR, Mundil R, Balco G, Min K, Ludwig KR (2010) Joint determination of ${ }^{40} \mathrm{~K}$ decay constants and ${ }^{40} \mathrm{Ar} * /{ }^{40} \mathrm{~K}$ for the Fish Canyon sanidine standard, and improved accuracy for ${ }^{40} \mathrm{Ar} /{ }^{39} \mathrm{Ar}$ geochronology. Geochim Cosmochim Act 74:5349-5367. doi:10.1016/ j.gca.2010.06.017

Roeder PL, Emslie RF (1970) Olivine-liquid equilibrium. Contrib Miner Pet 29:275-289. doi:10.1007/BF00371276

Ruch J, Manconi A, Zeni G, Solaro G, Pepe A, Shirzaei M, Walter TR, Lanari R (2009) Stress transfer in the Lazufre volcanic area, central Andes. Geophys Res Lett 36:L22303. doi:10.1029/2009GL041276

Scaillet, S., Rotolo, S.G., La Felice, S., Vita-Scaillet, G., 2011. High-resolution ${ }^{40} \mathrm{Ar} /{ }^{39} \mathrm{Ar}$ chronostratigraphy of the post-caldera $(<20 \mathrm{ka})$ volcanic activity at Pantelleria, Sicily Strait. Earth and Planetary Science Letters 309, 280-290.

Scaillet S, Vita-Scaillet G, Guillou H (2008) Oldest human footprints dated by Ar/Ar. Earth Planet Sci Lett 275:320-325. doi:10.1016/j.epsl.2008.08.026

Schöpa A, Annen C (2013) The effects of magma flux variations on the formation and lifetime of large silicic magma chambers. J Geophys Res Solid Earth. doi: 10.1002/jgrb.50127

Schwarz M (2000) Tephrakorrelation im östlichen Mittelmeer (Meteor M40/4 Kerne). Ph.D., Albert-Ludwigs-Universität Freiburg i. Br.

Sigurdsson H, Carey S, Alexandri M, Vougioukalakis G, Croff K, Roman C, Sakellariou D, Anagnostou C, Rousakis G, Ioakim C, Gogou A, Ballas D, Misaridis T, Nomikou P (2006) 
Marine investigations of Greece's Santorini volcanic field. Eos Trans Am Geophys Union 87:337-348. doi:200610.1029/2006EO340001

Sisson TW, Bacon CR (1999) Gas-driven filter pressing in magmas. Geology 27:613-616. doi:10.1130/0091-7613(1999)027<0613:GDFPIM>2.3.CO;2

Smith RL (1979) Ash-flow magmatism. Geol Soc Am Spec Pap 180:5-28. doi:10.1130/SPE180-p5

Solano JMS, Jackson MD, Sparks RSJ, Blundy JD, Annen C (2012) Melt segregation in deep crustal hot zones: a mechanism for chemical differentiation, crustal assimilation and the formation of evolved magmas. J Pet 53:1999-2026. doi:10.1093/petrology/egs041

Sparks RSJ, Folkes CB, Humphreys MCS, Barfod DN, Clavero J, Sunagua MC, McNutt SR, Pritchard ME (2008) Uturuncu volcano, Bolivia: Volcanic unrest due to mid-crustal magma intrusion. Am J Sci 308:727-769. doi:10.2475/06.2008.01

St Seymour K, Christanis K, Bouzinos A, Papazisimou S, Papatheodorou G, Moran E, Denes G (2004) Tephrostratigraphy and tephrochronology in the Philippi peat basin, Macedonia, Northern Hellas (Greece). Quat Int 121:53-65. doi:10.1016/j.quaint.2004.01.023

Stevenson DJ (1989) Spontaneous small-scale melt segregation in partial melts undergoing deformation. Geophys Res Lett 16:1067-1070. doi:10.1029/GL016i009p01067

Stormer JC (1983) The effects of recalculation on estimates of temperature and oxygen fugacity from analyses of multicomponent iron-titanium oxides. Am Miner 68:586-594.

Sutton AN, Blake S, Wilson CJN, Charlier BLA (2000) Late Quaternary evolution of a hyperactive rhyolite magmatic system: Taupo volcanic centre, New Zealand. J Geol Soc 157:537-552. doi:10.1144/jgs.157.3.537

Thunell R, Federman A, Sparks S, Williams D (1979) The age, origin, and volcanological significance of the Y-5 ash layer in the Mediterranean. Quat Res 12:241-253. doi:10.1016/ 0033-5894(79)90060-7

Tirel C, Gueydan F, Tiberi C, Brun J-P (2004) Aegean crustal thickness inferred from gravity inversion. Geodynamical implications. Earth Planet Sci Lett 228:267-280. doi:10.1016/ j.epsl.2004.10.023

Vaggelli G, Pellegrini M, Vougioukalakis G, Innocenti S, Francalanci L (2009) Highly Sr radiogenic tholeiitic magmas in the latest inter-Plinian activity of Santorini volcano, Greece. J Geophys Res 114:B06201. doi:10.1029/2008JB005936

Vespa M, Keller J, Gertisser R (2006) Interplinian explosive activity of Santorini volcano (Greece) during the past 150,000 years. J Volcanol Geotherm Res 153:262-286. doi:10.1016/ j.jvolgeores.2005.12.009

Vinci A (1985) Distribution and chemical composition of tephra layers from Eastern Mediterranean abyssal sediments. Mar Geol 64:143-155. doi:10.1016/0025-3227(85)90165-3

Wark DA, Hildreth W, Spear FS, Cherniak DJ, Watson EB (2007) Pre-eruption recharge of the Bishop magma system. Geology 35:235-238. doi:10.1130/G23316A.1 
Wilson CJN, Charlier BLA (2009) Rapid Rates of Magma Generation at Contemporaneous Magma Systems, Taupo Volcano, New Zealand: Insights from U-Th Model-age Spectra in Zircons. J Pet 50:875-907. doi:10.1093/petrology/egp023

Wulf S, Kraml M, Kuhn T, Schwarz M, Inthorn M, Keller J, Kuscu I, Halbach P (2002) Marine tephra from the Cape Riva eruption (22 ka) of Santorini in the Sea of Marmara. Mar Geol 183:131-141. doi:10.1016/S0025-3227(01)00302-4

Zellmer G, Turner S, Hawkesworth C (2000) Timescales of destructive plate margin magmatism: new insights from Santorini, Aegean volcanic arc. Earth Planet Sci Lett 174:265-281. doi:10.1016/S0012-821X(99)00266-6

Zellmer GF, Sparks RSJ, Hawkesworth CJ, Wiedenbeck M (2003) Magma emplacement and remobilization timescales beneath Montserrat: insights from $\mathrm{Sr}$ and $\mathrm{Ba}$ zonation in plagioclase phenocrysts. J Pet 44:1413 -1431. doi:10.1093/petrology/44.8.1413 


\section{Tables}

Table $1 \mathrm{New}{ }^{40} \mathrm{Ar} /{ }^{39} \mathrm{Ar}$-ages for the Therasia dacites

\begin{tabular}{cccc}
\hline Sample & Unit & Gauss-plot age (ka) & Weighted mean age (ka) \\
\hline SAN 09-43 & Flow 25 & $25.3 \pm 1.4$ & $24.6 \pm 1.3$ \\
SAN 10-13 & Flow 21 & $33.1 \pm 1.1$ & $33.2 \pm 1.1$ \\
SAN 10-12 & Flow 3 & $40.1 \pm 2.2$ & $39.4 \pm 2.2$ \\
SAN 10-11 & Flow 1 & $49.4 \pm 2.5$ & $48.2 \pm 2.4$ \\
\hline
\end{tabular}

Table 2 Published ages for the Cape Riva eruption. The average of these ages is

$21.8 \pm 0.4 \mathrm{ka}(2 \sigma)$

\begin{tabular}{|c|c|c|c|c|}
\hline $\begin{array}{l}\text { Uncalibrated } \\
{ }^{14} \mathrm{C} \text { age }(\mathrm{ka})^{\mathrm{a}}\end{array}$ & $\begin{array}{c}\text { Calibrated age } \\
\text { (ka) }\end{array}$ & Method & Sample dated & Reference \\
\hline $\begin{array}{l}18.05 \pm 0.34 \\
18.17 \pm 0.21 \\
18.88 \pm 0.23\end{array}$ & $\begin{array}{l}21.46 \pm 0.49^{b} \\
21.63 \pm 0.33^{b} \\
22.47 \pm 0.24^{b}\end{array}$ & ${ }^{14} \mathrm{C}$ & $\begin{array}{l}\text { Charred trees from } \\
\text { ignimbrite }\end{array}$ & $\begin{array}{l}\text { Pichler and Friedrich } \\
\text { (1976) }\end{array}$ \\
\hline $18.15 \pm 0.20$ & $21.60 \pm 0.32^{b}$ & ${ }^{14} \mathrm{C}$ & $\begin{array}{l}\text { Charcoal from } \\
\text { ignimbrite }\end{array}$ & Eriksen et al. (1990) \\
\hline $\begin{array}{l}17.38 \pm 0.23 \\
18.53 \pm 0.15 \\
18.24 \pm 0.14\end{array}$ & $\begin{array}{l}20.53 \pm 0.26^{b} \\
21.75 \pm 0.24^{b} \\
22.14 \pm 0.17^{b}\end{array}$ & ${ }^{14} \mathrm{C}$ & $\begin{array}{l}\text { Peat below Y-2 } \\
\text { tephra, Philippi basin, } \\
\text { Greece }\end{array}$ & $\begin{array}{l}\text { St Seymour et al. } \\
(2004)\end{array}$ \\
\hline \multirow[t]{2}{*}{ - } & 21.62 & $\begin{array}{l}\text { Interpolation between } \\
\text { sapropels dated using }{ }^{14} \mathrm{C}\end{array}$ & & Asku et al. (2008) \\
\hline & $19^{c}$ & $\begin{array}{l}\text { Interpolation between } \\
\text { istopic stages dated by } \\
{ }^{231} \mathrm{~Pa} /{ }^{230} \mathrm{Th}\end{array}$ & & Thunell et al. (1979) \\
\hline
\end{tabular}


Table 3 Representative whole rock and groundmass analyses of the Therasia and Cape Riva products

\begin{tabular}{|c|c|c|c|c|c|c|c|c|c|}
\hline & $\begin{array}{l}\text { Therasia Mafic } \\
\text { Enclave }\end{array}$ & $\begin{array}{l}\text { Upper Therasia } \\
\text { Andesite }\end{array}$ & Therasia Dacite & Cape Riva Andesite & Cape Riva Dacite & $\begin{array}{l}\text { Upper Therasia } \\
\text { Andesite }\end{array}$ & Therasia Dacite & Cape Riva Andesite & Cape Riva Dacite \\
\hline & Whole Rock & Whole Rock & Whole Rock & Scoria & Pumice & Groundmass & Groundmass & Groundmass & Groundmass \\
\hline Sample & GS10-43 & GS10-22 & GS10-17 & S09-41 & S09-40 & GS10-22 & GS10-17 & S09-41 & S09-40 \\
\hline Unit & Flow 22 & Flow 22 & Flow 5 & Cape Riva A & Cape Riva A & Flow 22 & Flow 5 & Cape Riva A & Cape Riva A \\
\hline \multicolumn{10}{|c|}{ Major elements (ICP-AES, wt\% dry) } \\
\hline $\mathrm{SiO}_{2}$ & 51.87 & 60.26 & 66.00 & 60.19 & 65.84 & 63.67 & 67.99 & 61.53 & 69.88 \\
\hline $\mathrm{Al}_{2} \mathrm{O}_{3}$ & 19.07 & 17.16 & 15.38 & 16.43 & 15.40 & 15.44 & 14.70 & 16.98 & 15.05 \\
\hline $\mathrm{TiO}_{2}$ & 0.89 & 0.86 & 0.75 & 0.88 & 0.76 & 0.79 & 0.63 & 0.74 & 0.48 \\
\hline $\mathrm{FeO}_{\mathrm{T}}{ }^{\mathrm{a}}$ & 8.08 & 6.05 & 4.66 & 6.58 & 4.88 & 5.60 & 4.03 & 5.96 & 3.31 \\
\hline $\mathrm{MgO}$ & 5.44 & 2.66 & 1.08 & 3.17 & 1.16 & 2.39 & 0.85 & 2.62 & 0.53 \\
\hline $\mathrm{CaO}$ & 10.16 & 5.98 & 3.15 & 6.20 & 3.28 & 4.62 & 2.34 & 5.86 & 2.14 \\
\hline $\mathrm{Na}_{2} \mathrm{O}$ & 3.30 & 4.52 & 5.48 & 4.63 & 5.84 & 4.55 & 5.91 & 4.92 & 5.86 \\
\hline $\mathrm{K}_{2} \mathrm{O}$ & 0.90 & 2.18 & 3.19 & 1.56 & 2.45 & 2.60 & 3.25 & 1.82 & 2.95 \\
\hline $\mathrm{MnO}$ & 0.16 & 0.14 & 0.13 & 0.16 & 0.16 & 0.14 & 0.12 & 0.15 & 0.12 \\
\hline $\mathrm{P}_{2} \mathrm{O}_{5}$ & 0.14 & 0.19 & 0.18 & 0.19 & 0.22 & 0.20 & 0.19 & 0.17 & 0.16 \\
\hline \multicolumn{10}{|c|}{ Trace elements (ICP-MS, ppm) } \\
\hline $\mathrm{Li}$ & 16.20 & 18.10 & 25.50 & 16.4 & 17.4 & 20.3 & 26.9 & 17.7 & 20.4 \\
\hline $\mathrm{Sc}$ & 25.90 & 17.40 & 13.90 & 23.4 & 13.8 & 18.5 & 14.2 & 24.6 & 14.8 \\
\hline $\mathrm{V}$ & 193.0 & 109.0 & 30.1 & 139.0 & 30.2 & 80.8 & 14.5 & 126 & 8.3 \\
\hline $\mathrm{Cr}$ & 31.30 & 9.52 & 1.17 & 27.10 & 0.60 & 8.41 & 0.76 & 21.2 & 4.33 \\
\hline $\mathrm{Ni}$ & 15.80 & 5.65 & 0.86 & 14.20 & 2.57 & 4.62 & 0.75 & 14.6 & 5.48 \\
\hline $\mathrm{Rb}$ & 25.8 & 68.1 & 104.0 & 50.0 & 71.7 & 89 & 105 & 60.2 & 101 \\
\hline $\mathrm{Sr}$ & 323 & 231 & 133 & 185 & 127 & 176 & 108 & 197 & 105 \\
\hline Y & 23.8 & 37.9 & 50.8 & 38.5 & 45.9 & 44.9 & 53.6 & 44.2 & 61.1 \\
\hline $\mathrm{Zr}$ & 108 & 200 & 321 & 175 & 250 & 271 & 334 & 214 & 341 \\
\hline $\mathrm{Nb}$ & 4.71 & 9.47 & 12.90 & 7.12 & 9.44 & 11.4 & 13.3 & 7.58 & 11.6 \\
\hline $\mathrm{Ba}$ & 251 & 391 & 513 & 297 & 375 & 455 & 542 & 323 & 460 \\
\hline $\mathrm{La}$ & 11.9 & 23.5 & 32.2 & 19.0 & 23.7 & 27.9 & 33.9 & 20.5 & 28.9 \\
\hline $\mathrm{Ce}$ & 26.9 & 49.5 & 66.5 & 40.7 & 50.5 & 63.2 & 70.2 & 43.6 & 61.6 \\
\hline $\operatorname{Pr}$ & 3.37 & 5.93 & 7.70 & 4.98 & 6.09 & 7.07 & 8.22 & 5.41 & 7.4 \\
\hline $\mathrm{Nd}$ & 14.2 & 23.4 & 30.1 & 20.4 & 24.6 & 27.9 & 31.9 & 21.6 & 29.5 \\
\hline
\end{tabular}




\begin{tabular}{|c|c|c|c|c|c|c|c|c|c|}
\hline $\mathrm{Sm}$ & 3.43 & 5.40 & 6.91 & 5.14 & 5.77 & 6.31 & 7.16 & 5.28 & 7.09 \\
\hline $\mathrm{Eu}$ & 0.97 & 1.29 & 1.43 & 1.29 & 1.34 & 1.20 & 1.33 & 1.27 & 1.28 \\
\hline $\mathrm{Gd}$ & 3.67 & 5.57 & 7.14 & 5.56 & 6.44 & 6.40 & 7.35 & 5.68 & 7.5 \\
\hline $\mathrm{Tb}$ & 0.62 & 0.92 & 1.20 & 0.95 & 1.07 & 1.09 & 1.27 & 0.966 & 1.29 \\
\hline Dy & 3.92 & 5.96 & 7.94 & 6.16 & 7.06 & 7.12 & 8.43 & 6.58 & 8.58 \\
\hline Ho & 0.84 & 1.27 & 1.68 & 1.33 & 1.54 & 1.51 & 1.80 & 1.41 & 1.87 \\
\hline $\mathrm{Er}$ & 2.53 & 3.89 & 5.20 & 4.11 & 4.77 & 4.64 & 5.53 & 4.32 & 5.81 \\
\hline $\mathrm{Yb}$ & 2.42 & 3.94 & 5.30 & 4.08 & 4.92 & 4.69 & 5.74 & 4.37 & 6.09 \\
\hline $\mathrm{Lu}$ & 0.37 & 0.59 & 0.81 & 0.62 & 0.75 & 0.72 & 0.87 & 0.663 & 0.938 \\
\hline $\mathrm{Hf}$ & 2.78 & 5.27 & 7.51 & 4.69 & 6.22 & 6.73 & 8.38 & 5.14 & 8.07 \\
\hline $\mathrm{Ta}$ & 0.29 & 0.63 & 0.92 & 0.50 & 0.64 & 0.81 & 0.98 & 0.52 & 0.819 \\
\hline
\end{tabular}

${ }^{\mathrm{a}} \mathrm{FeO}_{\mathrm{T}}$ is the total $\mathrm{FeO}$ and $\mathrm{Fe}_{2} \mathrm{O}_{3}$ content calculated as $\mathrm{FeO}$ 
Table 4 Calculation for the mixing of (1) Therasia dacite plus Therasia basalt (mafic enclave) to produce the upper Therasia hybrid andesite, and (2) Cape Riva dacite plus Skaros basalt to produce the Cape Riva hybrid andesite. For the upper Therasia andesite, the mixing proportions are 38:62 mafic:silicic. For the Cape Riva andesite, the proportions are 36:64. Calculated using the PetroGraph software of Petrelli et al. (2005)

\begin{tabular}{|c|c|c|c|c|c|c|c|c|c|c|}
\hline & \multirow[b]{2}{*}{$\begin{array}{l}\text { Mean Therasia } \\
\text { Dacite }\end{array}$} & \multirow[b]{2}{*}{$\begin{array}{l}\text { Mafic Enclave } \\
\text { (GS10-43) }\end{array}$} & \multicolumn{3}{|c|}{ Upper Therasia Hybrid Andesite } & \multirow[b]{2}{*}{$\begin{array}{l}\text { Mean Cape Riva } \\
\text { Dacite }\end{array}$} & \multirow[b]{2}{*}{$\begin{array}{l}\text { Mean Skaros } \\
\text { Basalt }\end{array}$} & \multicolumn{3}{|c|}{ Cape Riva Hybrid Andesite } \\
\hline & & & Calculated & $\begin{array}{l}\text { Measured } \\
(\text { GS10-22) }\end{array}$ & Residual & & & Calculated & Mean Measured & Residual \\
\hline \multicolumn{11}{|c|}{ Major Elements (wt\%) } \\
\hline $\mathrm{SiO}_{2}$ & 65.50 & 51.86 & 60.28 & 60.26 & 0.02 & 66.41 & 52.16 & 61.22 & 61.14 & 0.08 \\
\hline $\mathrm{TiO}_{2}$ & 0.83 & 0.89 & 0.85 & 0.86 & -0.01 & 0.74 & 0.87 & 0.79 & 0.83 & -0.04 \\
\hline $\mathrm{Al}_{2} \mathrm{O}_{3}$ & 15.51 & 19.07 & 16.87 & 17.16 & -0.29 & 15.46 & 18.38 & 16.52 & 16.39 & 0.13 \\
\hline $\mathrm{FeO}_{\text {tot }}$ & 4.93 & 8.08 & 6.13 & 6.05 & 0.08 & 4.75 & 8.20 & 6.01 & 6.27 & -0.26 \\
\hline $\mathrm{MnO}$ & 0.14 & 0.16 & 0.15 & 0.14 & 0.01 & 0.15 & 0.17 & 0.16 & 0.15 & 0.01 \\
\hline $\mathrm{MgO}$ & 1.21 & 5.44 & 2.83 & 2.66 & 0.17 & 1.23 & 5.96 & 2.95 & 2.93 & 0.02 \\
\hline $\mathrm{CaO}$ & 3.41 & 10.16 & 5.99 & 5.98 & 0.01 & 3.35 & 10.78 & 6.06 & 5.92 & 0.14 \\
\hline $\mathrm{Na}_{2} \mathrm{O}$ & 5.50 & 3.30 & 4.66 & 4.52 & 0.14 & 5.33 & 2.72 & 4.38 & 4.53 & -0.15 \\
\hline $\mathrm{K}_{2} \mathrm{O}$ & 2.74 & 0.90 & 2.04 & 2.18 & -0.14 & 2.40 & 0.64 & 1.76 & 1.68 & 0.08 \\
\hline $\mathrm{P}_{2} \mathrm{O}_{5}$ & 0.23 & 0.14 & 0.20 & 0.19 & 0.01 & 0.18 & 0.12 & 0.16 & 0.15 & 0.01 \\
\hline \multirow[t]{2}{*}{ Total } & 100.00 & 100.00 & 100.00 & 100.00 & 0.00 & 100.00 & 100.00 & 100.00 & 100.00 & 0.00 \\
\hline & & \multicolumn{4}{|c|}{ Sum of the Squares: 0.16} & & & \multicolumn{3}{|c|}{ Sum of the Squares: 0.14} \\
\hline \multicolumn{11}{|c|}{ Trace Elements (ppm) } \\
\hline $\mathrm{Cr}$ & 2 & 31 & 13 & 10 & 3 & 8 & 82 & 35 & 33 & 2 \\
\hline $\mathrm{Ni}$ & 1 & 16 & 7 & 6 & 1 & 6 & 31 & 15 & 10 & 5 \\
\hline $\mathrm{Nb}$ & 12 & 5 & 9 & 9 & 0 & 10 & 4 & 8 & 8 & 0 \\
\hline $\mathrm{Rb}$ & 92 & 26 & 66 & 68 & -2 & 74 & 21 & 55 & 51 & 4 \\
\hline $\mathrm{Zr}$ & 291 & 108 & 221 & 200 & 21 & 266 & 94 & 203 & 193 & 10 \\
\hline $\mathrm{Sr}$ & 155 & 323 & 219 & 231 & -12 & 143 & 226 & 173 & 179 & -6 \\
\hline
\end{tabular}


Supplementary Table S1 Full ${ }^{40} \mathrm{Ar} /{ }^{39} \mathrm{Ar}$ data

Supplementary Table S2 Major element composition of glass from pumices in the Cape Tripiti deposit

Supplementary Table $\mathbf{S 3}$ Major element composition, temperature and $\mathrm{fO}_{2}$ determinations for pairs of magnetite and ilmenite from Therasia pumices.

Supplementary Table S4 Whole rock and groundmass chemical analyses of the Therasia and Cape Riva deposits 


\section{Figures}

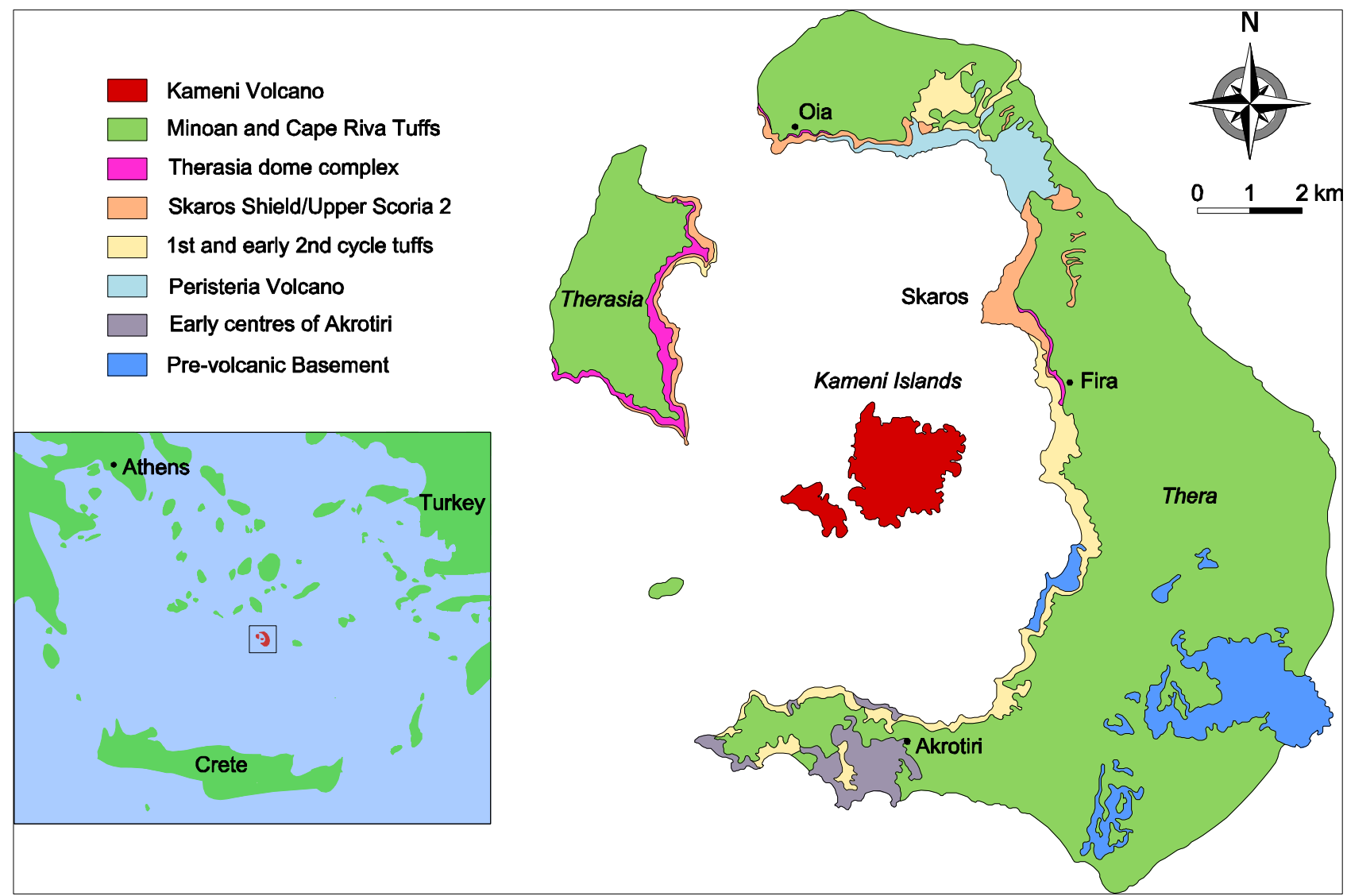

Fig. 1 Simplified geological map of Santorini, adapted from Druitt et al. (1999). Inset is a map of the Aegean region, with Santorini marked with a box 

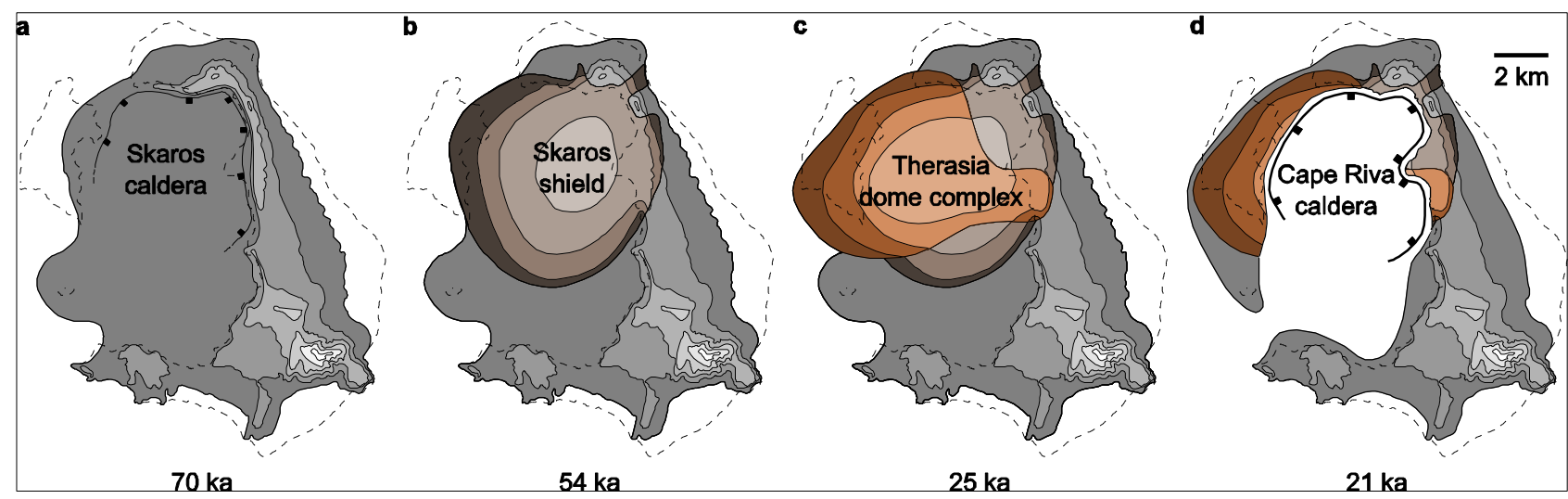

Fig. 2 Morphological evolution of Santorini between $70 \mathrm{ka}$ and $21 \mathrm{ka}$, after Druitt et al. (1999). The dashed line is the present-day outline of the islands. Contours are at $100 \mathrm{~m}$ intervals (a) The volcano after collapse of the Skaros caldera, which happened some time before the first Skaros lava was erupted at $69 \pm 7 \mathrm{ka}$ (b) The maximum extent of the Skaros shield, which culminated with the $54 \pm 3$ ka Upper Scoria 2 eruption (c) The maximum extent of Therasia dome complex at $\sim 25 \mathrm{ka} \mathrm{(d)} \mathrm{The} \mathrm{island} \mathrm{shortly} \mathrm{after} \mathrm{the} \sim 22 \mathrm{ka}$ Cape Riva eruption 

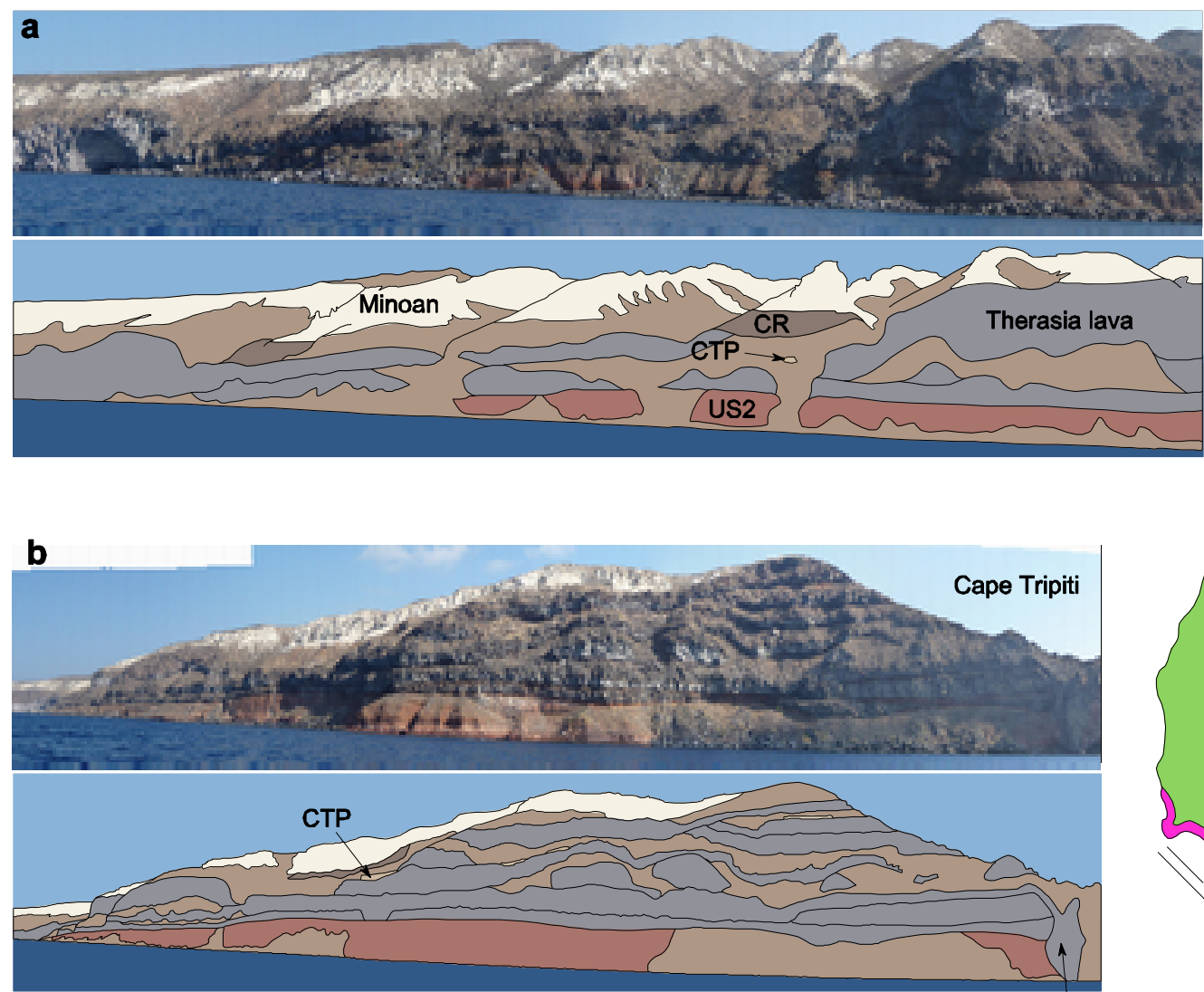

Dyke
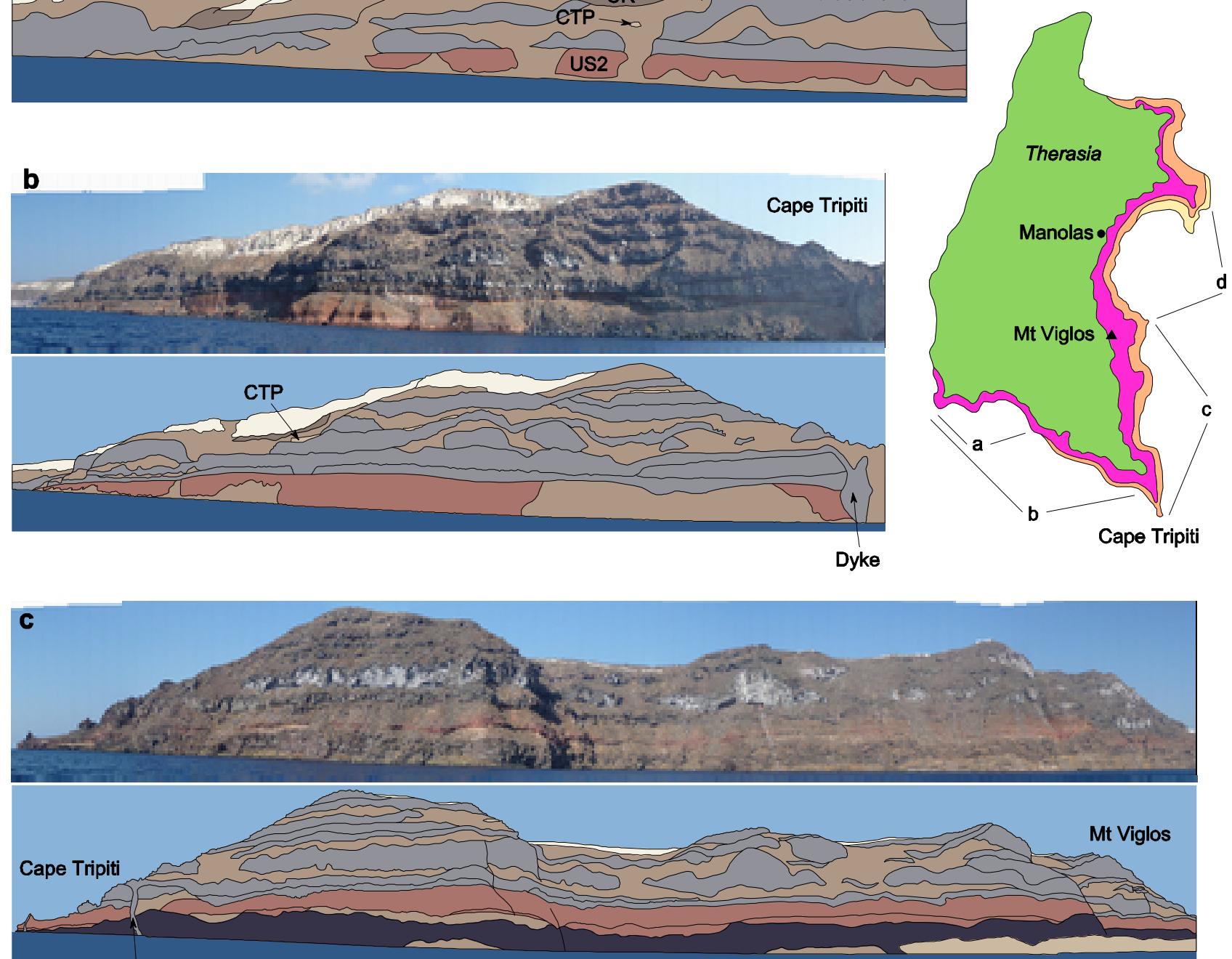

Dyke
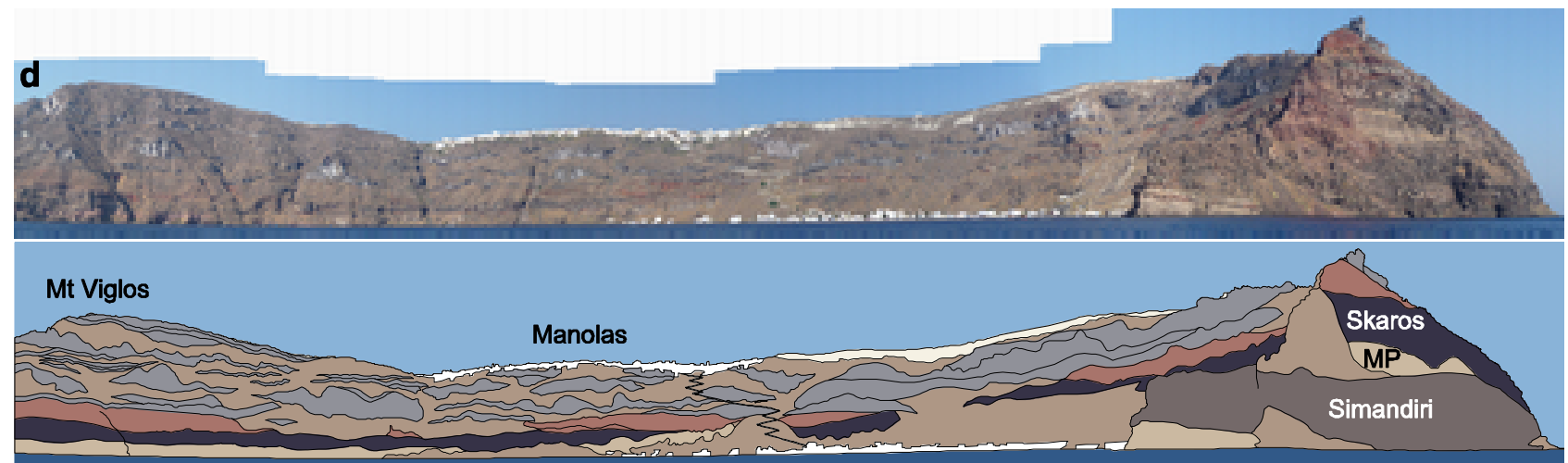
Fig. 3 Photos of the cliffs of Therasia, and the sketches drawn from them. Inset is a map of Therasia, showing where the photos of the cliffs were taken from. $\mathrm{CR}=$ Cape Riva, CTP $=$ Cape Tripiti Pumice, US2 $=$ Upper Scoria 2, MP = Middle Pumice

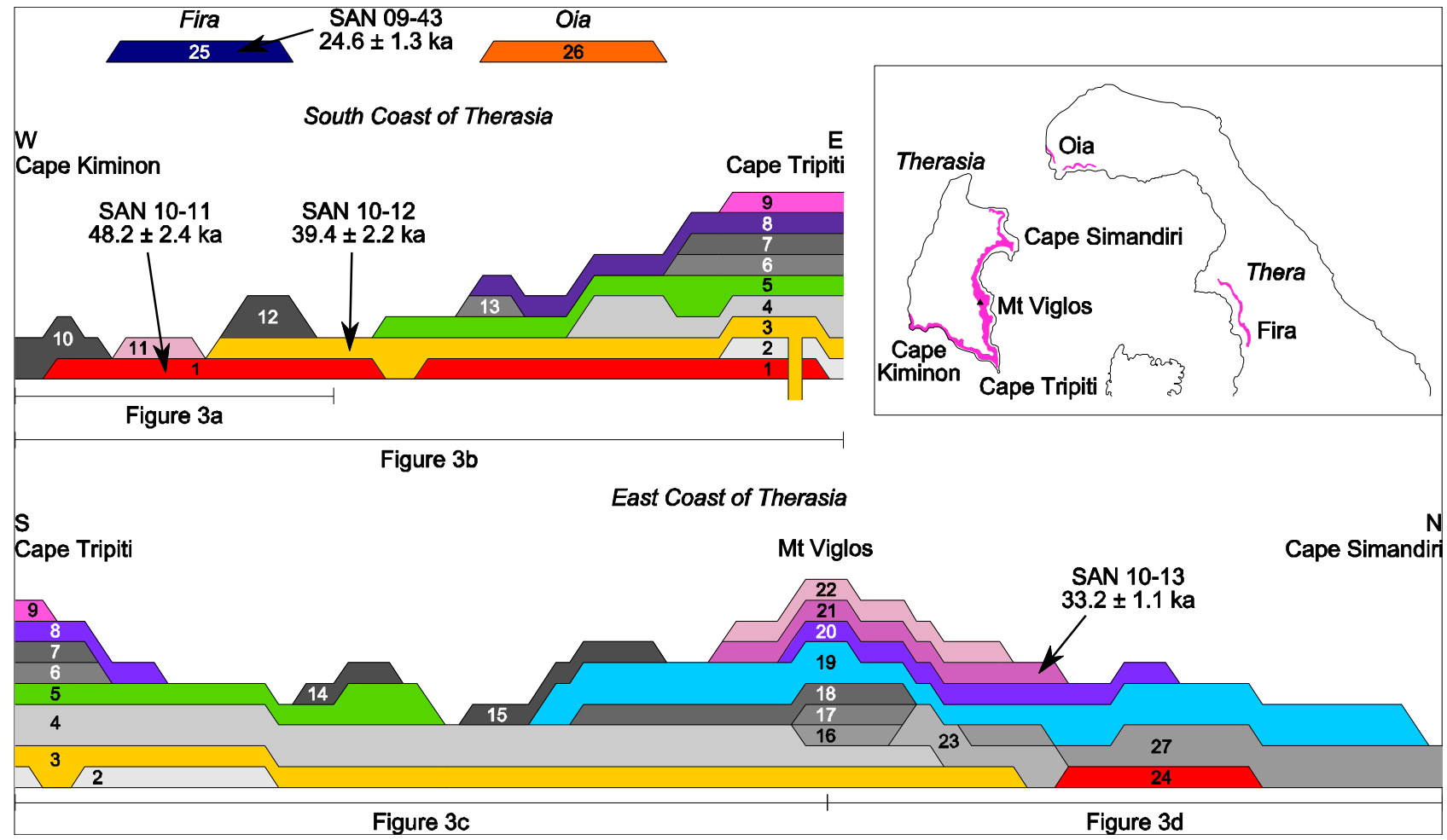

Fig. 4 Schematic representation of the different lava flows from the Therasia dome complex. Individual flow numbers are referred to in the text. Flows that were sampled and analysed are coloured, while unsampled flows are in grey. Where a correlation of two flows is made based on their chemistry, they are drawn in the same colour. Flows that have been ${ }^{40} \mathrm{Ar} /{ }^{39} \mathrm{Ar}$ dated are labelled with arrows; ${ }^{40} \mathrm{Ar} /{ }^{39} \mathrm{Ar}$ ages are weighted mean ages. The inset map has outcrops of the Therasia dome complex in pink 

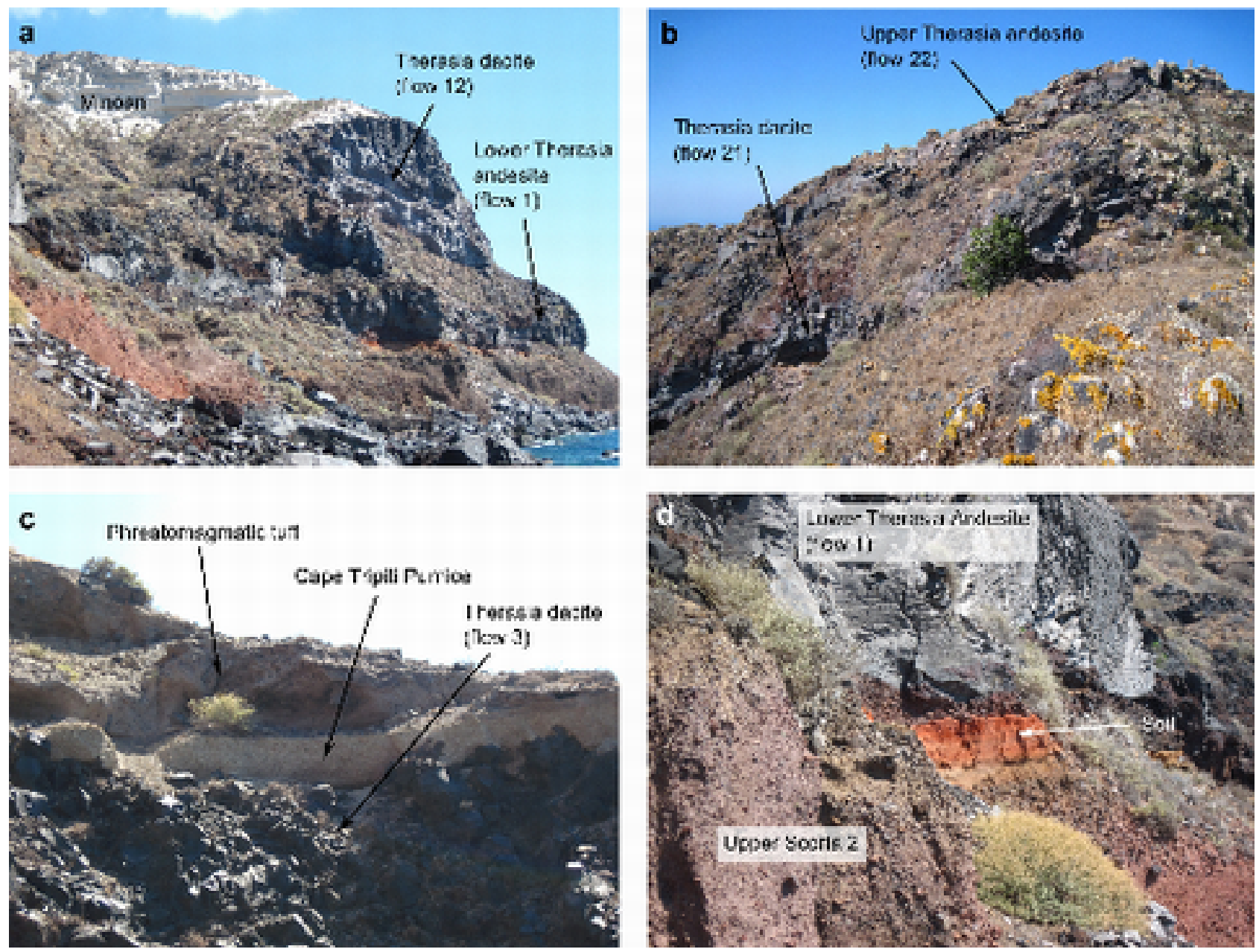

Fig. 5 Photos of the Therasia dome complex. (a) A thick dacitic dome above the lower Therasia andesite (b) The upper Therasia andesite on top of Mt Viglos (c) The Cape Tripiti pumice fall and an overlying phreatomagmatic tuff above lava flow 3 on the south coast of Therasia (d) The thick, orange soil between Upper Scoria 2 and the lower Therasia andesite 

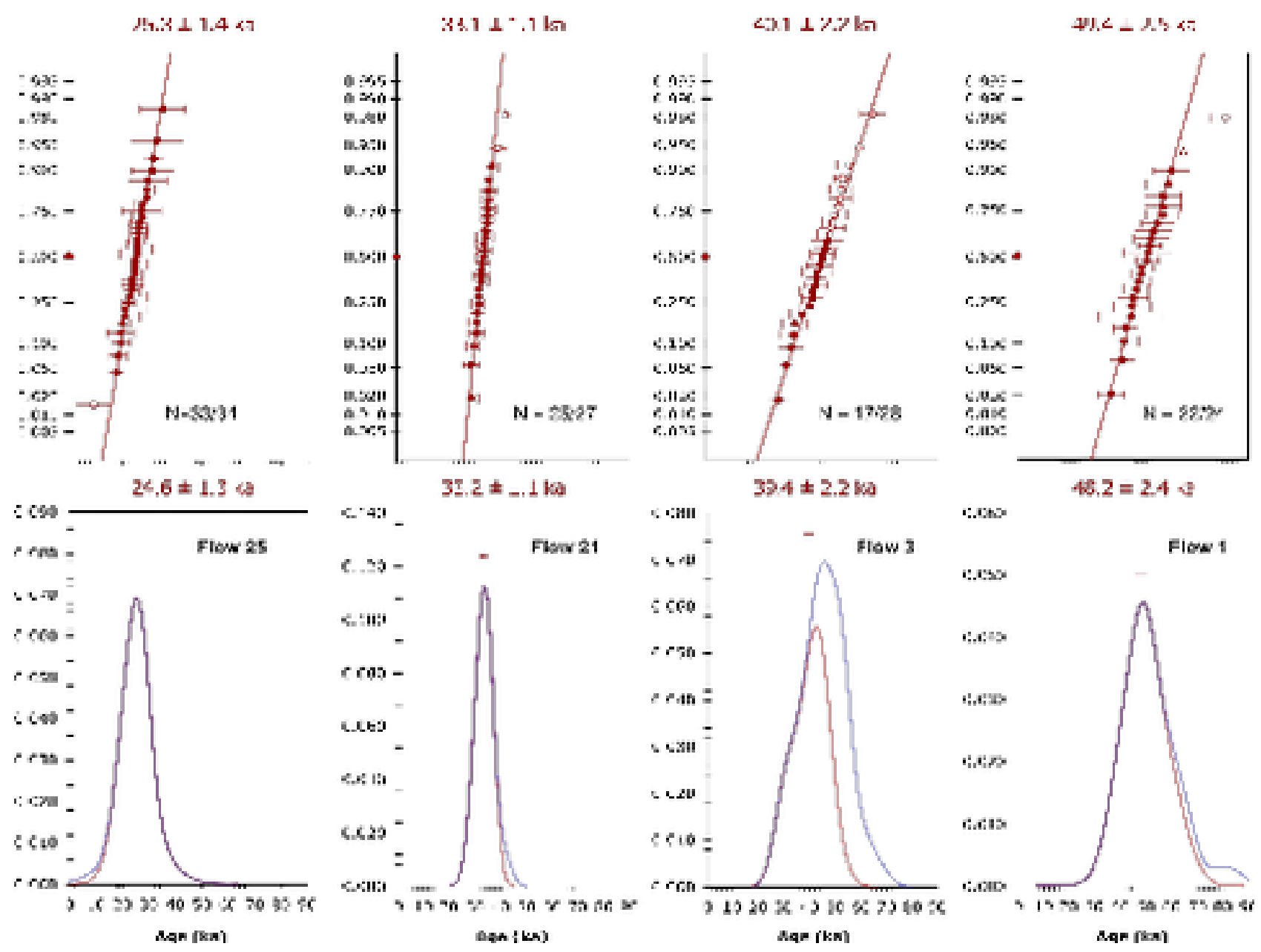

Fig. 6 Probability density plots (below) and Gauss plots (above) of ${ }^{40} \mathrm{Ar} /{ }^{39} \mathrm{Ar}$ data obtained on four lava flows dated in the Therasia sequence. Ages reported above each plot are $\pm 2 \sigma$ and represent inverse variance weighted mean ages (density plots) or best-fit apparent ages through the linear array (Gauss-plot). Empty symbols on Gauss-plots: data excluded from the fit. Red curve on density plots: density distribution with outlier removed; blue curve: density distribution of complete dataset. N: number of data points included in the fit over total number of runs for each sample. 


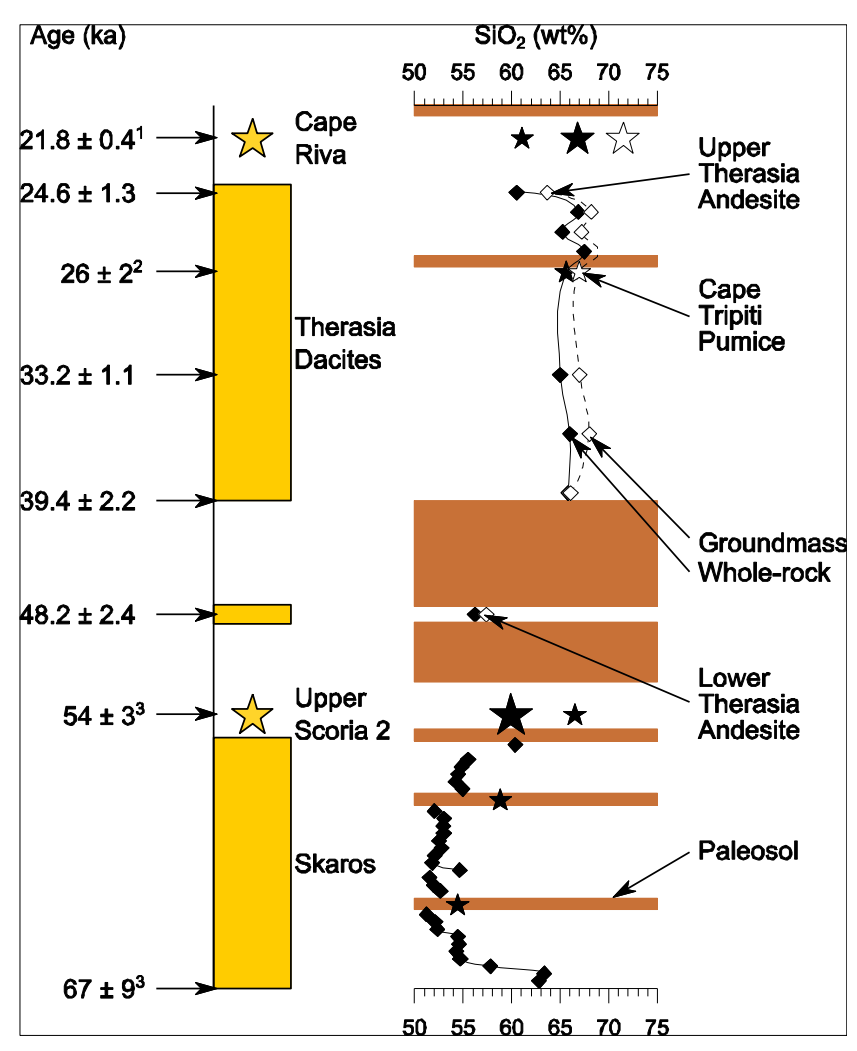

Fig. 7 Summary of magma compositions and ages between 70 and 20 ka. Major explosive eruptions are represented by stars, with periods of edifice construction coloured in yellow.

Periods of little or no preserved eruptive activity are left blank. The $\mathrm{SiO}_{2}$ content of the eruptive products is shown on the right. Black symbols are whole rock compositions, and white symbols are groundmass composition. Skaros data is taken from Huijsmans (1985) ${ }^{1}$ Data and citations in Table $2,{ }^{2}$ date taken from Schwarz $(2000){ }^{3}$ date taken from Druitt et al. (1999) 

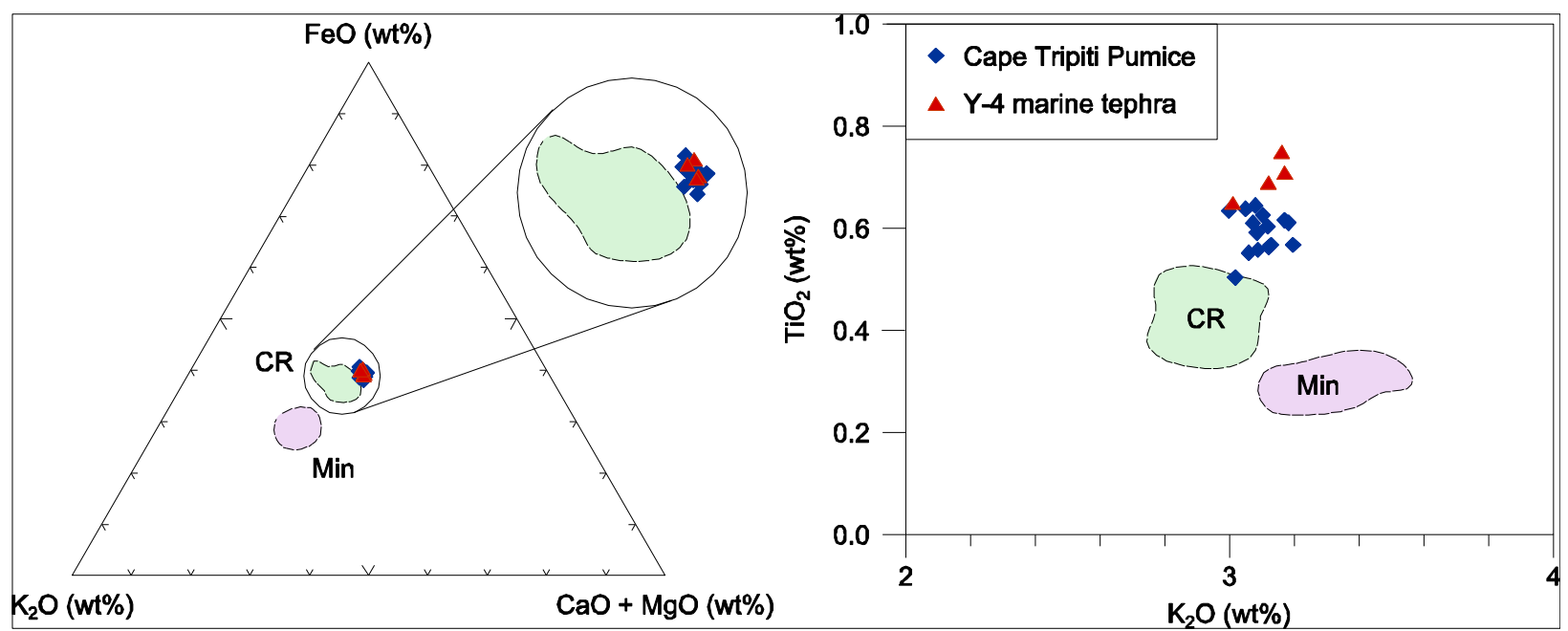

Fig. 8 Chemical discrimination plots for the Cape Tripiti pumice and Y-4 ash layer, after Wulf et al. (2002). The Y-4 data is taken from Vinci (1985) and Schwarz (2000) 


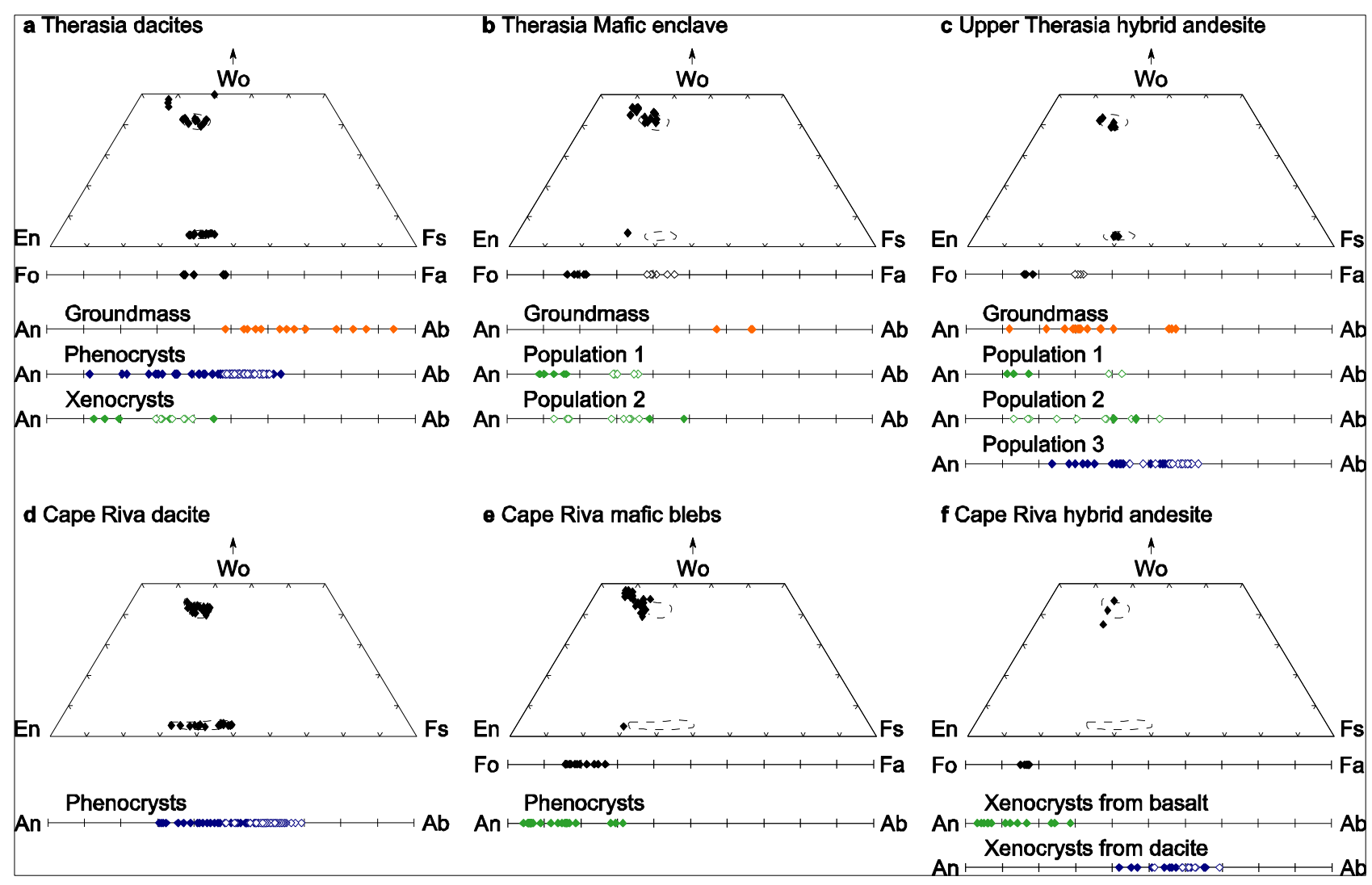

Fig. 9 Mineral compositions from the different rock units. Filled symbols are crystal cores or undifferentiated measurements, open symbols are crystal rims. Plagioclase populations are coloured according to their origin: orange symbols are groundmass crystals, blue symbols are populations that originated in a silicic magma and green symbols are populations that originated in a mafic magma. Some Cape Riva data taken from Druitt (1983). The fields of pyroxene compositions in the dacites (a, d) are shown on the other figures, for comparison. 


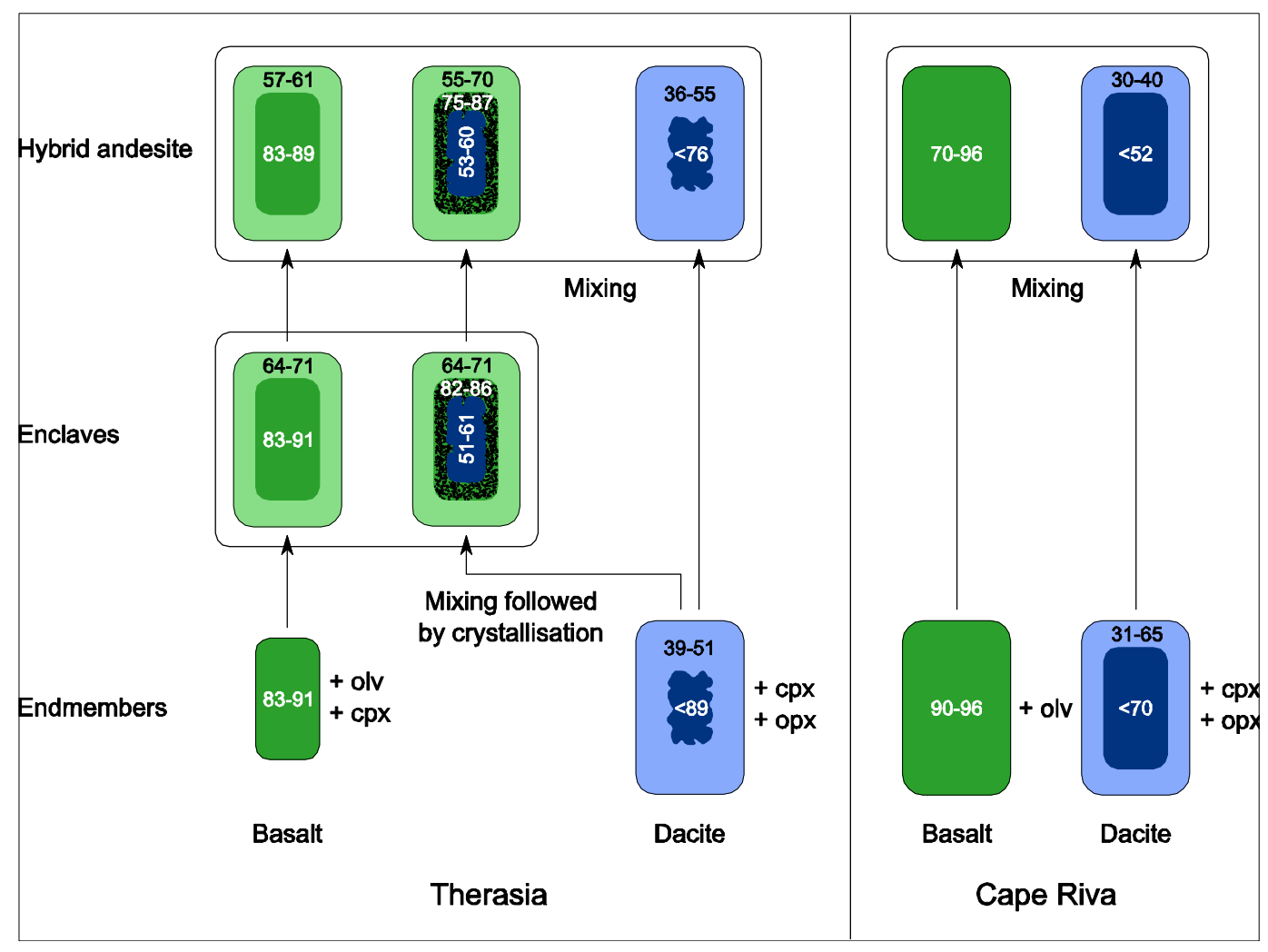

Fig. 10 Summary of plagioclase populations in the Cape Riva and Therasia rocks. The numbers are values of molar \% anorthite content of plagioclase 

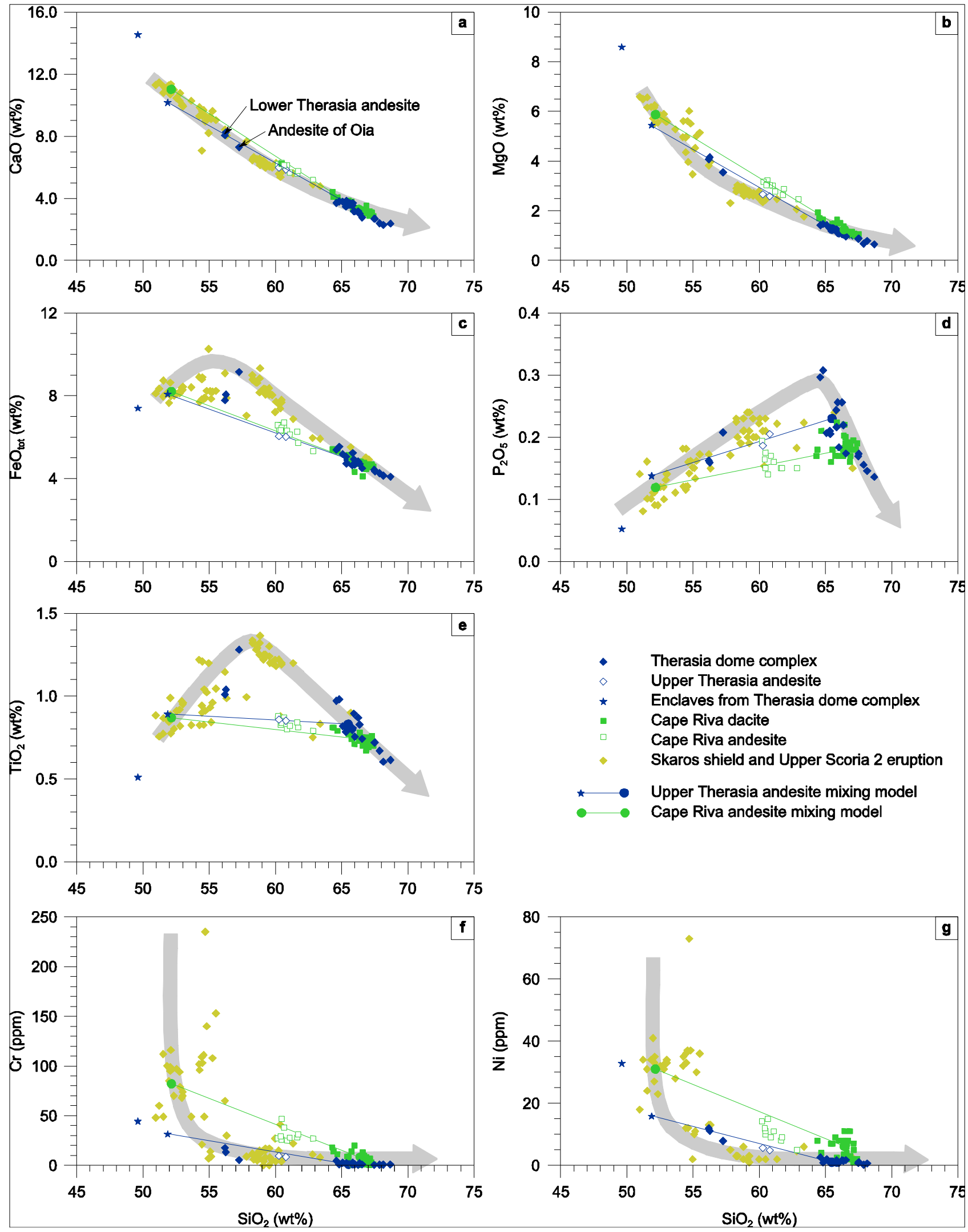
Fig. 11 variation diagrams of major elements and selected highly compatible trace elements. Mixing models for the upper Therasia andesite and the Cape Riva andesite are shown as blue and green lines, respectively. The mixing calculations are presented in Table 4. The typical fractionation trend for Santorini magmas discussed by Nicholls (1971), Mann (1983) and Druitt et al. (1999) is shown on the diagrams as a grey arrow. Composition of the Skaros lavas are also plotted for reference (Huijsmans 1985), as are scoria from the Upper Scoria 2 eruption (Druitt et al. 1999) 

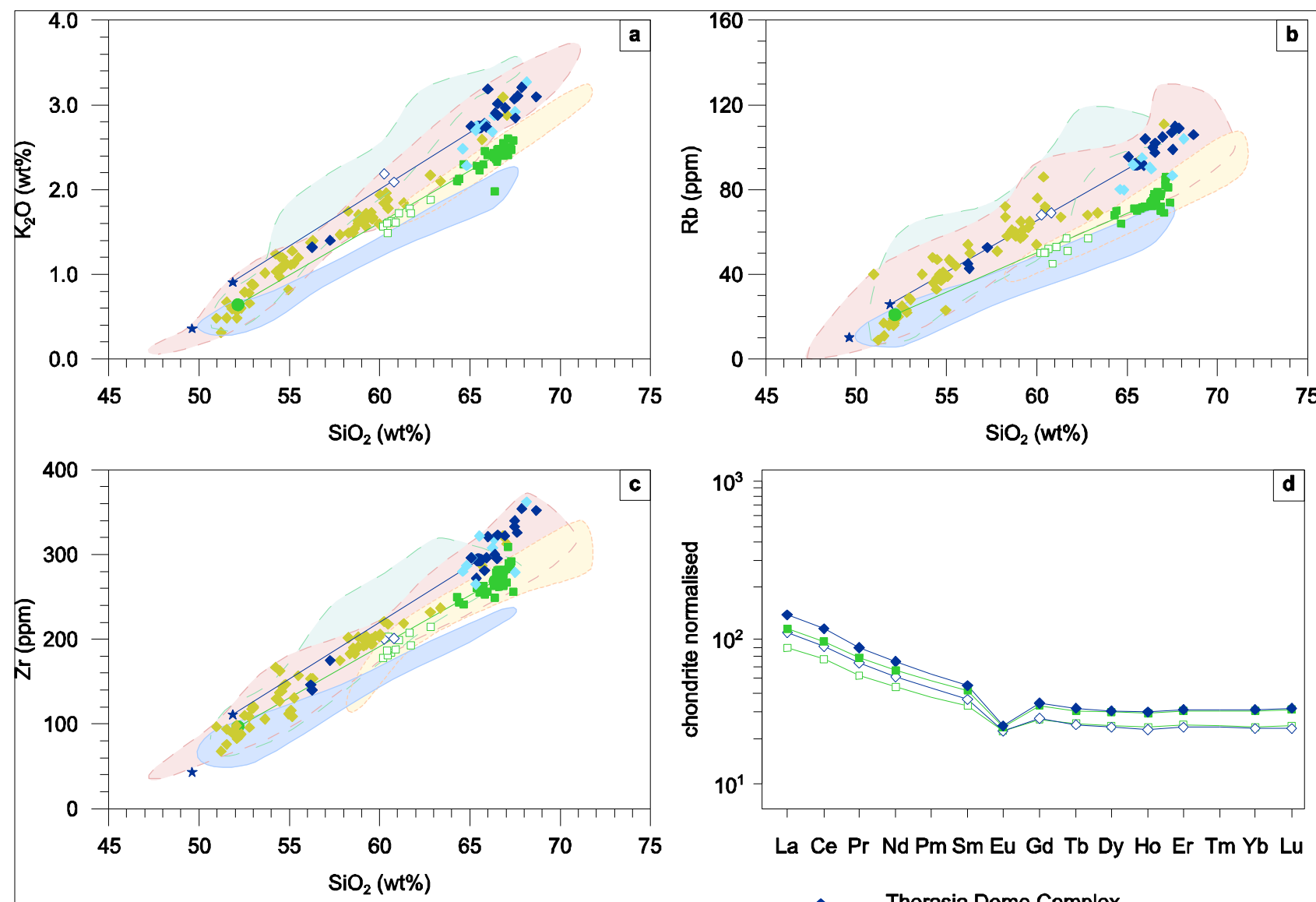

La Ce Pr Nd Pm Sm Eu Gd Tb Dy Ho Er Tm Yb Lu

Peristeria - Cape Therma 3 (530 - 196 ka)

Lower Pumice 1 - Therasia (184 - $22 \mathrm{ka}$ )

Cape Riva - Minoan (22 - 3.6 ka)

Kamenis $(<3.6 \mathrm{ka})$

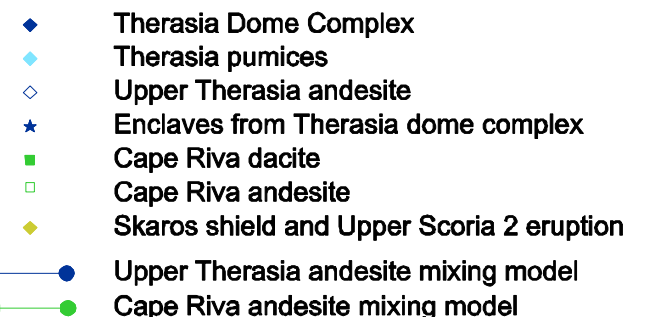

Fig. 12 Incompatible element variation diagrams. (a-c) Therasia and Cape Riva data are plotted as points, along with the Skaros data of Huijsmans (1985) and Upper Scoria 2 data of Druitt et al. (1999). Mixing models for the upper Therasia andesite and the Cape Riva andesite are plotted, as in Fig. 11. Fields of Santorini magma during the volcanic history since 530 ka are plotted, showing the long-term decrease in incompatible elements at Satonrini (Huijsmans 1985; Druitt et al. 1999; Martin 2005). (d) REE diagram showing the Therasia and Cape Riva magmas. The Therasia dacite is an average of 14 flows with $65-68 \mathrm{wt} \% \mathrm{SiO}_{2}$, and the Cape Riva dacite is an average of four analyses with $\mathrm{SiO}_{2}$ contents of $66-67 \mathrm{wt} \%$ (average: $66.5 \mathrm{wt} \%$ ). The upper Therasia andesite is an average of flows 11 and 22 (average $\mathrm{SiO}_{2}: 60.5 \mathrm{wt} \%$ ), and the Cape Riva andesite is an average 
of three analyses with $\mathrm{SiO}_{2}$ contents between $60.2-60.4 \mathrm{wt} \%$ (average: $60.4 \mathrm{wt} \%$ ). 